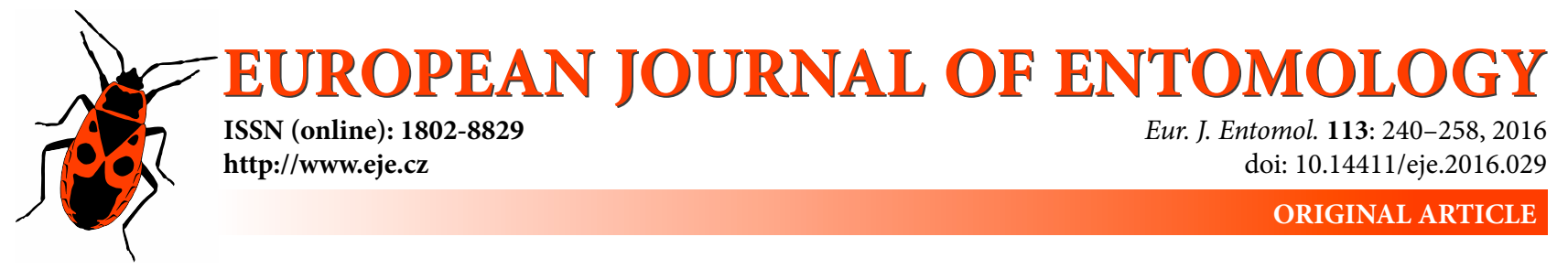

\title{
Revision of the attaphilous genus Phoxonotus (Coleoptera: Histeridae: Saprininae)
}

\section{TOMÁŠ LACKNER*}

Czech University of Life Sciences, Faculty of Forestry and Wood Sciences, Department of Forest Protection and Entomology, Kamýcká 1176, 16521 Praha 6 - Suchdol, Czech Republic; e-mail: tomaslackner@me.com

Key words. Coleoptera, Histeridae, Saprininae, Phoxonotus, revision, taxonomy, new subgenus, new species, new synonym, lectotype designation, biodiversity, morphology, Neotropical region

Abstract. In this paper the strictly attaphilous Central- and South American genus Phoxonotus Marseul, 1862 is revised. Based on the structure of their antennal cavities, the species of Phoxonotus are newly split into two subgenera: Phoxonotus Marseul, 1862 and Alienosternus subgen. n. (type species Saprinus venustus Erichson, 1834). The subgenus Phoxonotus contains three species: Phoxonotus (P.) tuberculatus Marseul, 1862 (French Guyana, Suriname, Brazil: Pará, Mato Grosso), P. (P.) lectus Lewis, 1902 (eastern Peru) and the newly described $P$. parvotuberculatus sp. n. (Guatemala, Costa Rica). The subgenus Alienosternus subgen. n. contains two species: Phoxonotus (Alienosternus) venustus (Erichson, 1834) (Brazil: Bahia) and $P$. (Alienosternus) fryi Lewis, 1879 (Brazil: Rio de Janeiro and Bahia). P. tuberculatus Marseul, 1862 is synonymized with P. suturalis Lewis, 1907, syn. n. Lectotype of Phoxonotus fryi Lewis, 1879 is designated. Genitalia of the males for the species for which they are available are illustrated, most type specimens are imaged and scanning electron micrographs of $P$. tuberculatus provided. Mouthparts and sensory structures of the antennal club of $P$. tuberculatus are depicted.

ZooBank Article LSID: 4C3BB497-274C-4E0E-B397-FCCD44AF8086

\section{INTRODUCTION}

Genus Phoxonotus was erected by Marseul (1862), most likely based on a single specimen of a newly described species $P$. tuberculatus. Lewis (1879) briefly described another species, $P$. fryi, based on several specimens; later he (Lewis, 1902) described another species, P. lectus, and redescribed $P$. fryi in more detail. Based on the description of Saprinus venustus Erichson, 1834, Lewis (1886: 280) transferred this species into the genus Phoxonotus most likely without ever examining the type specimen. Finally, Lewis (1908) added another species to the genus, $P$. suturalis, which he described based on a single specimen. From its establishment, the genus Phoxonotus was placed in the subfamily Dendrophilinae, based on the structure of its antennal cavity and prosternum, (see, e.g., Bickhardt, 1914, 1916 or Mazur, 1984). Although Lewis (1915) was the first to question Bickhardt's (1914) placement, it was Wenzel (unpubl.) who moved Phoxonotus into the Saprininae and this was adopted by Mazur in his last two catalogues (1997, 2011).

The present paper critically examines all of the type specimens of Phoxonotus (except for that of P. tuberculatus, which was not found), summarizes current knowledge of the genus and describes a new species from Guatemala and Costa Rica. This study is another contribution to ongoing revisionary work on the genera of the subfamily Saprininae (Lackner, 2009a-c, 2010, 2011a, b, 2012, 2013a, b, c, 2014a, b, c, d, 2015; Lackner \& Gomy, 2013, 2014; Lackner \& Tishechkin, 2014; Tishechkin \& Lackner, 2012).

\section{MATERIAL AND METHODS}

All dry-mounted specimens were relaxed in warm water for several hours. After removal from original cards, the beetles were side-mounted on triangular points and examined under a Nikon 102 binocular microscope using diffuse light. Male genitalia, mouthparts and antennae were first macerated in $10 \% \mathrm{KOH}$ solution for about 15 min, cleared in $80 \%$ alcohol and macerated in lactic acid with fuchsine, incubated at $60^{\circ} \mathrm{C}$ for another two hours, and subsequently transferred into $1: 1$ mixture of glacial acetic acid and methyl salicylate, heated at $60^{\circ} \mathrm{C}$ for $15 \mathrm{~min}$ and cleared in xylene. Genitalia, mouthparts and antennae were then examined in $\alpha$-terpineol in a small dish. Digital photographs of male genitalia were taken using a Nikon 4500 Coolpix camera and edited in Adobe Photoshop CS5. Based on the photographs or direct observations, illustrations were drawn using a Hakuba klv-7000 light-box. Colour photographs were taken by F. Slamka

\footnotetext{
* Present address: Bavarian State Collection of Zoology, Münchhausenstraße 21, 81247 Munich, Germany.
} 
(Bratislava, Slovakia); scanning electron micrographs (SEM) were taken at the laboratory of the Faculty of Agriculture, Hokkaido University, Sapporo, Japan. All specimens were measured using an ocular micrometer. Beetle terminology follows that of Ôhara (1994) and Lackner (2010).

The following acronyms of museum collections are used throughout the text: BMNH - The Natural History Museum, London, UK (R. Booth); CGA - Collection Gerardo Arriagada (Santiago de Chile, Chile); CND - Collection Nicolas Dégallier (Paris, France); CTL - Collection Tomáš Lackner (Munich, Germany); FMNH - Field Museum of Natural History, Chicago, USA (C. Maier); MNCR - Museo Nacional de Costa Rica, San José, Costa Rica (A. Ruiz); MNHN - Muséum National d'Histoire Naturelle, Paris, France (A. Taghavian); MNRJ - Museu Nacional, Universidade Federal do Rio de Janeiro (M.A. Monné); RMNH - National Centre for Biodiversity Naturalis, Leiden, The Netherlands (B. Brugge); USNM - United States National Museum, Smithsonian Institution, Washington D.C., USA (A.K. Tishechkin); ZMHB - Zoologisch Museum für Naturkunde, Humboldt-Universität, Berlin, Germany (B. Jaeger).

Abbreviations. Abbreviations of morphological measurements follow Ôhara (1994) and are used throughout the text as follows: APW - distance between anterior angles of pronotum; EL length of an elytron measured along elytral suture; EW - distance between outer margins of elytra; PEL - distance between anterior angle of pronotum and apex of elytra; PPW - distance between posterior angles of pronotum.

\section{RESULTS}

\section{Key to the subgenera and species of Phoxonotus}

1(7) Elytra without a row of four tubercles situated between the row of tubercles indicating the course of the fourth dorsal elytral stria and elytral suture (Fig. 1); antennal cavity formed by a small ovoid depression in the ventral part of the composite ventral plate (Fig. 30); carinal prosternal striae distinctly strongly divergent anteriorly, forming a rounded loop apically (Fig. 6) (Guatemala, Costa Rica, Peru, French Guyana, Suriname, Brazil: Pará, Mato Grosso) ... .subgenus Phoxonotus Marseul, 1862

2(6) Tubercles on pronotum large and prominent (Fig. 1); elytra with two rows of distinct tubercles (Fig. 1).

3(4) Mesoventrite sparsely punctate, punctures fine, separated by several times their diameter (Fig. 30); aedeagus dilated (Fig. 38) (eastern Peru)............ P. (Phoxonotus) lectus Lewis, 1902

4(3) Mesoventrite densely and rather coarsely punctate, punctures separated by approximately their diameter (Fig. 7); aedeagus thinner overall (Fig. 24) (French Guyana, Suriname, Brazil: Pará and Mato Grosso states)

P. (Phoxonotus) tuberculatus Marseul, 1862

6(2) Tubercles on pronotum not prominent, smaller (Fig. 40); elytra with only one small and faint tubercle on basal third of $3^{\text {rd }}$ dorsal elytral stria and with another, more prominent tubercle at the base of $4^{\text {th }}$ dorsal elytral stria (Fig. 40) (Guatemala, Costa Rica)... P. (Phoxonotus) parvotuberculatus sp. $\mathrm{n}$.

7(1) Elytra with a row of four tubercles situated between row of tubercles indicating the course of fourth dorsal elytral stria and elytral suture (Fig. 61); antennal cavity formed by the prosternal process and outer lateral costa of antennal groove (Fig. 64); carinal prosternal striae apically not forming a rounded loop, only weakly divergent anteriorly, distinctly angulate (Fig. 64) (Brazil: Bahia and Rio de Janeiro states)...... subgenus Alienosternus subgen. $\mathrm{n}$.

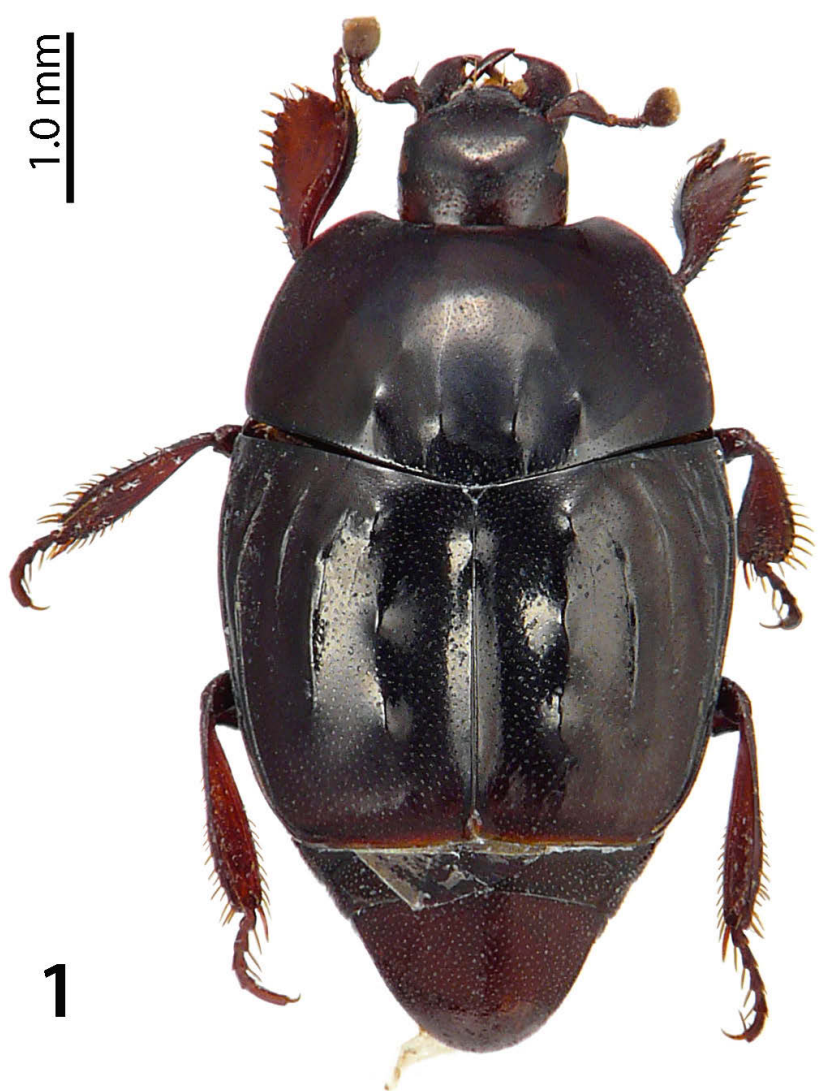

Fig. 1. Phoxonotus tuberculatus, male, habitus, dorsal view.

8(9) Spiculum gastrale gradually slightly dilated from approximately half its length, forming a distinct "head" with characteristic, downwardly curved lateral "arms" (Fig. 70) (Brazil: Rio de Janeiro and Bahia states).

.P. (Alienosternus) fryi Lewis, 1902

9(8) Apical third of spiculum gastrale abruptly triangularly dilated, but lacking downwardly curved arms and with short, inwardly curved lateral apices (Fig. 57) (Brazil: Bahia state) P. (Alienosternus) venustus (Erichson, 1834)

\section{Genus Phoxonotus Marseul, 1862}

Phoxonotus Marseul, 1862: 35; Bickhardt (1916): 109; Mazur (1984): 114; Mazur (1997): 217; Mazur (2011): 178.

Type species: Phoxonotus tuberculatus Marseul, 1862: 37, by monotypy.

Diagnosis. Ovoid, dorsally convex, light to dark brown non-metallic beetles with (prominent) tubercles on pronotum and elytra. Dorsum of body usually wholly punctate; apical pronotal angles prominent, pronotal hypomeron or body venter asetose. Frontal stria always interrupted and prolonged onto clypeus. Pronotal depressions absent, marginal pronotal stria single, carinate. Marginal elytral and inner subhumeral striae usually complete, carinate; elytral disc with striae 1-3 usually marked, stria 4 often marked by only a row of tubercles; in subgenus Alienosternus there is another row of tubercles between $4^{\text {th }}$ stria and elytral suture; in P. tuberculatus a single tubercle is also present on elytral suture near elytral base. Antennal cavity either a small depression in the ventral part of the composite plate (subgenus Phoxonotus; Fig. 30) or formed by the 

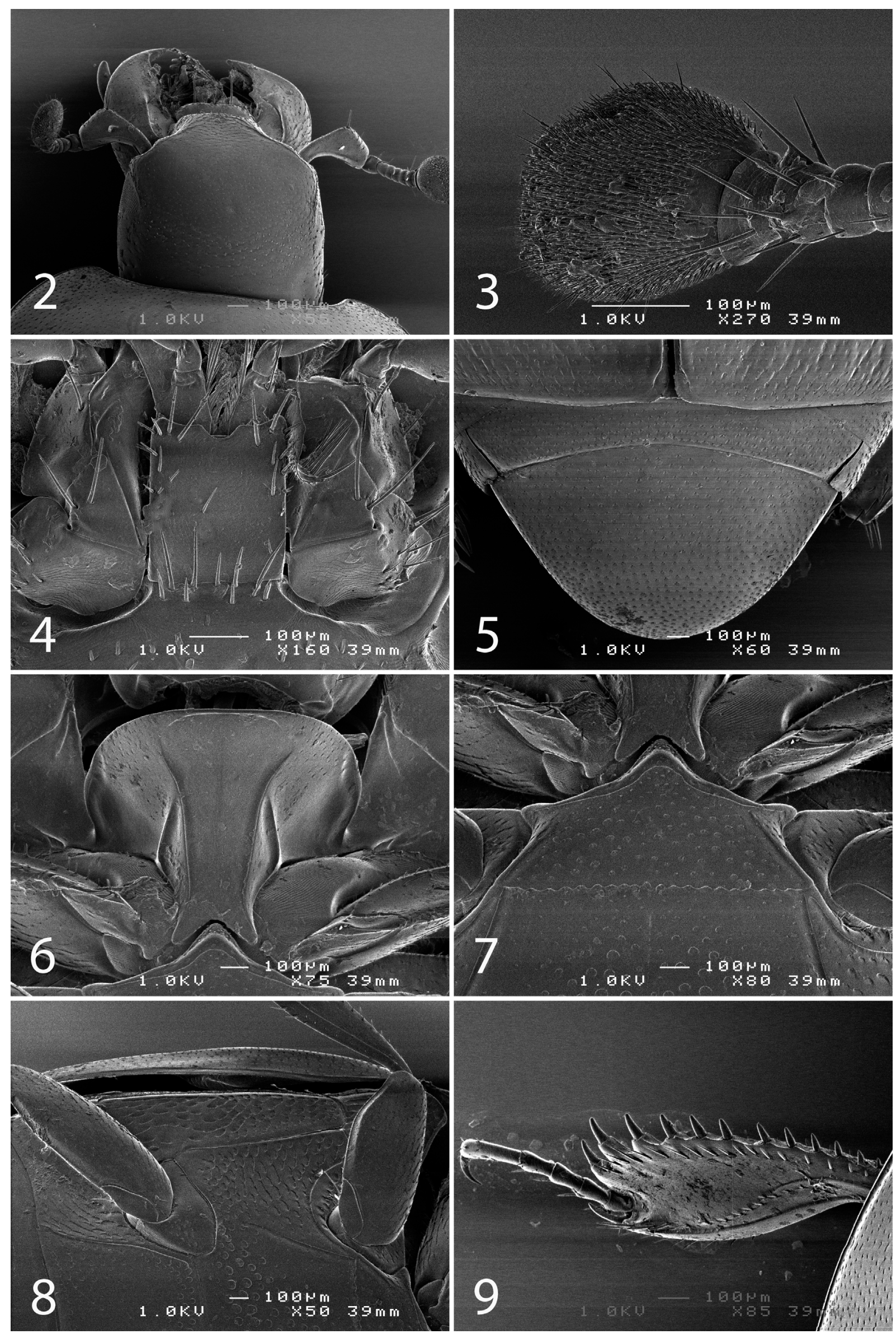

Figs 2-9: Phoxonotus tuberculatus, female. 2 - head, dorsal view; 3 - antennal club, ventral view; 4 - mentum, ventral view; 5 - propygydium and pygidium; 6 - prosternum; 7 - mesoventrite; 8 - lateral disc on metaventrite and metepisternum; 9 - protibia, dorsal view. 

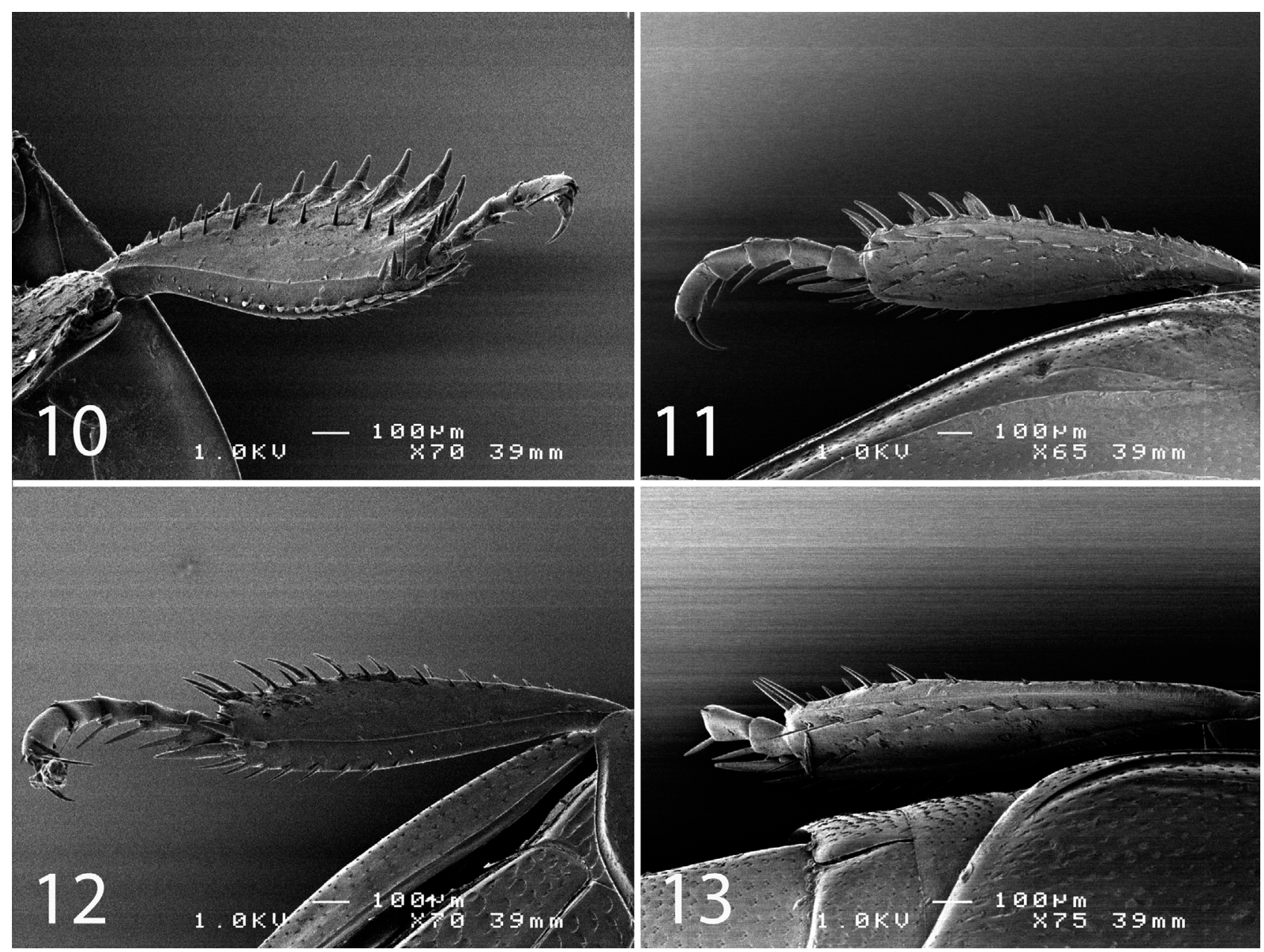

Figs 10-13: Phoxonotus tuberculatus, female. 10 - protibia, ventral view; 11 - mesotibia, dorsal view; 12 - ditto, ventral view; 13 - metatibia, dorsal view.

prosternal process and outer lateral costa of the antennal groove (subgenus Alienosternus; Fig. 64). Anterior third of prosternal process always elevated and broadened; carinal prosternal striae always divergent anteriorly, in the nominotypical subgenus forming a round loop; surface between carinal prosternal striae in one species with faint longitudinal tubercle. Apical part of mesoventrite protruding and fitting into base of prosternal process. Apex of eighth sternite of male genitalia with an accessory sclerite (Figs 17, 31, 42, 65); concealed under setae in P. venustus and P. fryi.

Differential diagnosis. An unmistakable genus whose external morphology does not resemble any other taxon of currently known Saprininae. Among the phylogenetically meaningful characters are the deeply incised base of the prosternum, formed to accommodate the acutely angulate apex of the mesoventrite (no other currently known Saprininae taxon exhibits this feature); unique tubercles on pronotum and/or elytra (likewise absent in all other currently known Saprininae taxa); accessory sclerite of eighth sternite of male genitalia (absent in most Saprininae taxa); and absence of the sutural elytral stria (this stria is, interestingly, also absent in several other, apparently unrelated myrmecophilous or termitophilous forms, e.g., Myrmetes paykulli Kanaar, 1979 and an undescribed myrmecophilous genus from Australia: Lackner \& Leschen, forthcoming).
Biology. Reichensperger (1935) was the first to state that members of Phoxonotus are attaphilous based on a series of specimens of P. fryi collected from the nests of Atta ants. This was confirmed by Kanaar (1997) who published a paper on attaphilous Histeridae from Suriname, which includes scores of Phoxonotus tuberculatus collected by D.C. Geijskes in detritus chambers of both Atta sexdens and $A$. cephalotes. I was able to examine specimens of $P$. tuberculatus mentioned by Kanaar (1997); one specimen of $P$. tuberculatus was collected using a flight interception trap. The two Guatemalan specimens of the newly described $P$. parvotuberculatus were collected in a large 6-8 feet (1.8-2.4 m) deep detritus cavity of a species of Atta. Biological data for other species of Phoxonotus are lacking.

Distribution. Central- and South America: known from Costa Rica, Brazil, Peru, French Guyana and Suriname (Fig. 74).

\section{Subgenus Phoxonotus Marseul, 1862}

Differential diagnosis. Differs from members of Alienosternus subgen. $\mathrm{n}$. in the structure of the antennal cavity, which in Phoxonotus is a small oval depression in the ventral part of the composite plate, whereas in Alienosternus it is formed by the prosternal process and outer lateral costa of the antennal groove (compare Figs 30 and 

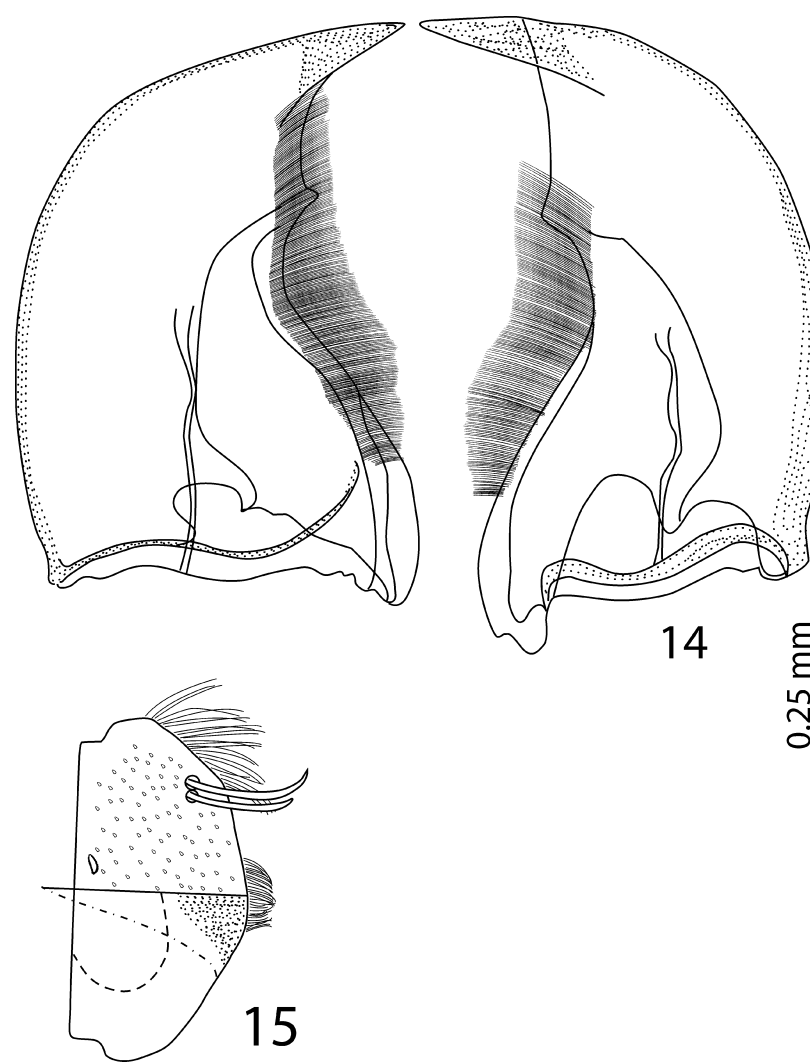

हี

Figs 14-15: Phoxonotus tuberculatus, female. 14 - mandibles, dorsal view; 15 - labrum, left half depicting dorsal and right half depicting ventral structures.

64). Further differences lie in the structure of the carinal prosternal striae that apically form a rounded loop in Phoxonotus and are distinctly angulate apically in Alienosternus (compare Figs 6 and 64). Moreover, the number and structure of the elytral tubercles differ between subgenera: elytra of the subgenus Phoxonotus lack the row of tubercles between the rows of tubercles indicating the course of the fourth dorsal elytral stria and elytral suture, which is present in members of Alienosternus (compare Figs 1 and 61). Apices of the eighth sternite of the male genitalia are much less setose in Phoxonotus than in Alienosternus (compare Figs 17, 31 and 42 with 52 and 65).

Biology. See Biology of Phoxonotus s. 1.

Distribution. Members of the nominotypical subgenus are known from Guatemala, Costa Rica, eastern Peru, French Guyana, Suriname and Brazil: Pará, Mato Grosso.

\section{Phoxonotus (Phoxonotus) tuberculatus Marseul, 1862}

(Figs 1-26)

Phoxonotus tuberculatus Marseul, 1862: 37, Fig. 1a-c; Bickhardt (1916): 109; Mazur (1984): 114; Kanaar (1997): 277; Mazur (1997): 217; Dégallier \& Kanaar (2001): 206, Figs 107-109; Mazur (2011): 178.

Phoxonotus suturalis Lewis, 1907, syn. n.

Type locality. French Guyana, Cayenne.

Type material examined. Phoxonotus suturalis Lewis, 1907, holotype, $\bigcirc$, with the following labels: "O" (printed); followed by: Obidos, Amazonas / H. Rolle, / Berlin, S.W.11 (black-framed label, printed); followed by: "Type" (red-margined round label,

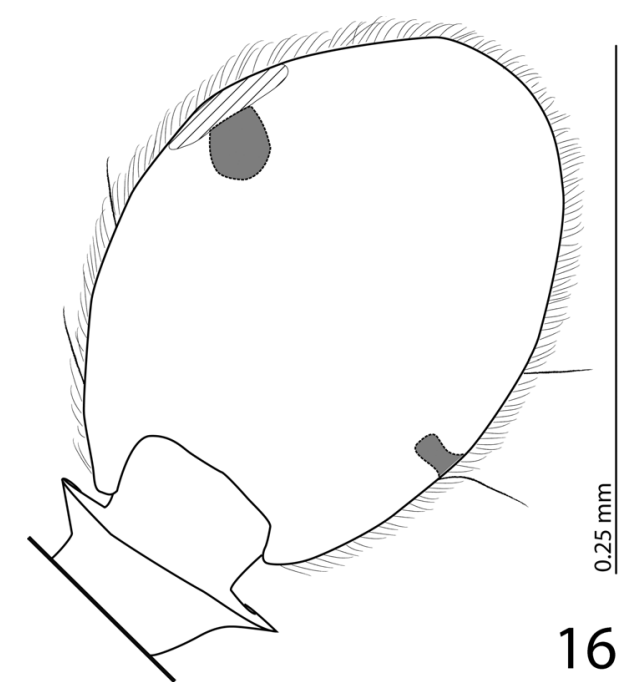

Fig. 16. Phoxonotus tuberculatus, female, antennal club depicting sensory structures.

printed); followed by: "Phoxonotus / suturalis / Type / Lewis (written) (BMNH).

Note. The type specimen(s) of P. tuberculatus Marseul, 1862 were not located in the collection of S.A. Marseul, which is now part of the general collection of MNHN. According to the collection curator (A. Taghavian, pers. comm., 2014), it is possible that the type is elsewhere in the collection and therefore I am hesitant to designate a neotype pending the discovery of the original type specimen(s) of Marseul. Furthermore, the existence of a single specimen from "Cayenne" in the general collection of MNHN is mentioned by Dégallier \& Kanaar (2001: 206). The following redescription is therefore based on the available material from French Guyana (which is the type locality) and Suriname, which is a neighbouring country, and carefully compared with Marseul's description (1862).

Additional material examined. FRENCH GUYANA: 1옹 Kourou, "ancienne RN", 31.xii.1982, N. Dégallier leg. (CGA); 1 ㅇ, Montagne des Cheveaux, Roura, $4^{\circ} 43^{\prime} \mathrm{N}, 52^{\circ} 24^{\prime}$ W, 4.i.2009, FIT 1.5 m, S.E.A.G. leg. (CND). SURINAME: $1 \delta^{\Uparrow}+1 q$, Lelydorp, 6.-16.xii.1938, D.C. Geijskes leg., in detritus room of Atta sexdens nest (NCB); $7 \hat{\jmath}+3$, , Paramaribo-Charlesburg, 5.ix.1938, D.C. Geijskes leg., in detritus room of Atta cephalotes nest (RMNH); 1 + , ibid, but CND. BRAZIL: Mato Grosso: 1 ㅇ, Mpio, Querencia, Fazenda, São Luiz, $560 \mathrm{~m}, 12^{\circ} 38.819^{\prime} \mathrm{S}$, $52^{\circ} 22.492^{\prime} \mathrm{W}$, Flight Intercept trap, vii.2008, R. Andrade (USNM).

Redescription. Body (Fig. 1) PEL $=3.25-3.65 \mathrm{~mm}$; $\mathrm{APW}=1.25-1.50 \mathrm{~mm} ; \mathrm{PPW}=2.50-2.70 \mathrm{~mm} ; \mathrm{EW}=$ 2.75-3.10 mm; EL = 2.00-2.25 mm; oval, dorsally convex, ventrally flattened, cuticle light to dark brown, without metallic lustre, wholly punctuate; punctures more prominent on elytra and metaventrite than on rest of body. Body appendages similarly coloured; antennal club lighter, ambercoloured.

Head: frons (Fig. 2) feebly convex, frontal disc covered with microscopic punctures, frontal stria widely interrupted, prolonged onto clypeus; supraorbital stria indistinct; clypeus slightly depressed, subtrapezoidal, margined anteriorly, disc on clypeus with elongate fine, almost confluent punctures. Eyes rather small, inconspicuous from above. Antennal scape with several thin setae dorsally, rather 


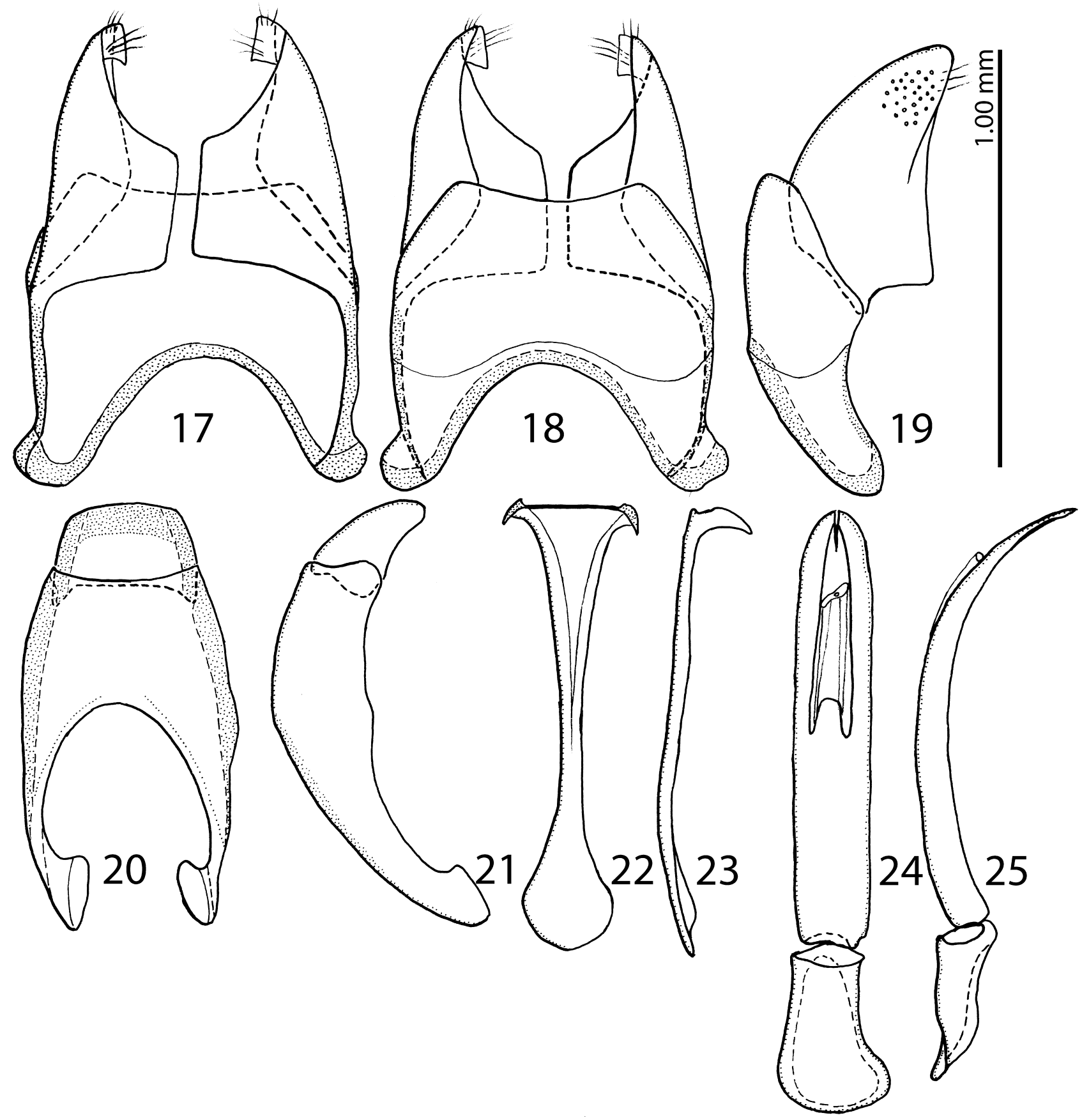

Fig. 17-25: Phoxonotus tuberculatus, male. 17 - eighth sternite and tergite, ventral view; 18 - ditto, dorsal view; 19 - ditto, lateral view; 20 - ninth and tenth tergites, dorsal view; 21 - ditto, lateral view; 22 - spiculum gastrale, ventral view; 23 - ditto, lateral view; 24 - aedeagus, dorsal view; 25 - ditto, lateral view.

long, elbowed, slender, fitting into deep furrow situated below eye laterad to mandibular base when head is retracted. Pedicel approximately twice as long as each $3^{\text {rd }}$ to $7^{\text {th }}$ antennal segment; antennal club (Fig. 3) oval, without apparent intersegmental sutures (although Marseul in his original description mentions them; see Remarks below), flattened dorsoventrally, completely covered with dense short sensilla intermingled with sparse much longer erect sensilla; sensory structures on the antenna (Fig. 16) in form of a single pear-shaped vesicle situated on internal distal margin of antennal club under small inconspicuous round sensory area; another, smaller pacifier-like vesicle situated on external proximal margin of antennal club without a complementary sensory area. Mandibles (Fig. 14) large, robust, microscopically wrinkled laterally, pointed apically; subapical tooth of left mandible blunt. Labrum (Fig. 15) wholly punctate, subtrapezoidal; basal half of labral disc distinctly elevated, apical half situated lower than basal; a pair of large labral pits situated near the lateral margin of labral disc, pits furnished each with two unusually long, slender labral setae. Setae of epipharynx rather long and dense, distinctly protruding. Labral process absent. Maxilla: cardo subrectangular, apical margin with two long thin setae, basal margin with numerous shorter setae; stipes 


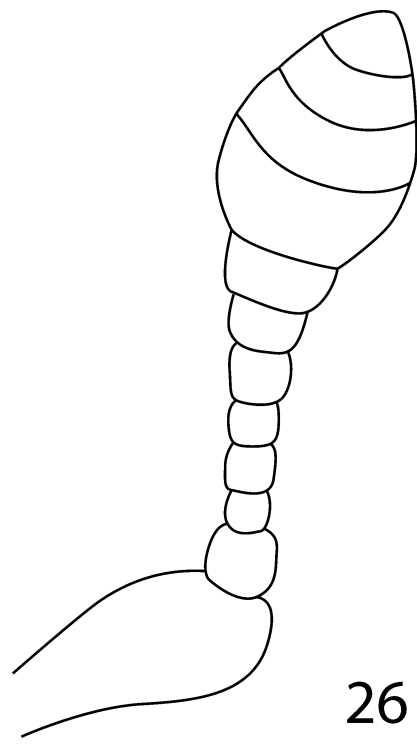

Fig. 26. Antenna of Phoxonotus tuberculatus, re-drawn from Marseul (1862).

rather small, triangular, with two thin rather long setae. Lacinia approximately three times smaller than galea, lacinial hook (= uncus) absent; galea with two distinct sclerites and large brush of dense long setae. Terminal maxillary palpomere slender, elongated, approximately four times longer than penultimate, narrowing apically, palpal organ inconspicuous (= absent?) Mentum (Fig. 4) subquadrate, slightly longer than wide, apical margin with prominent notch, disc of mentum smooth, laterally furnished with two rows of irregular short setae, anterior margin in anterolateral angles each with two longer setae.

Pronotum distinctly convex, moderately narrowing anteriorly, anterior angles prominent, anterior pronotal margin with deep incision for head. Marginal pronotal stria present, thin, slightly carinate laterally, anteriorly very thin, almost inconspicuous. Pronotal disc with rather dense microscopic punctuation, punctures separated by several times their diameter, punctures do not become coarser or denser laterally. Pronotal base with a row of four equallyspaced prominent tubercles: two outer ones almost round, globular, while two inner ones larger than two outer ones, elongate. Another two, distinctly smaller and lower tubercles each situated anterad of outermost tubercles of first row; tubercles of both rows form together an imaginary trapezoid. Pronotal depressions absent, prescutellar depression faint; pronotal hypomeron asetose, glabrous. Scutellum small, triangular.

Elytra widest across humeri, wholly punctuate, punctures separated by twice to several times their diameter, more prominent along elytral suture. Elytral epipleuron almost smooth, marginal epipleural stria fine, complete; marginal elytral stria carinate and complete; apical elytral stria absent. Inner subhumeral stria long, carinate and complete, subparallel to marginal elytral stria, for short distance continuous along elytral apex. Oblique humeral stria faint, occasionally doubled. Elytral disc with three distinct dorsal elytral striae (in several specimens from Suriname the third

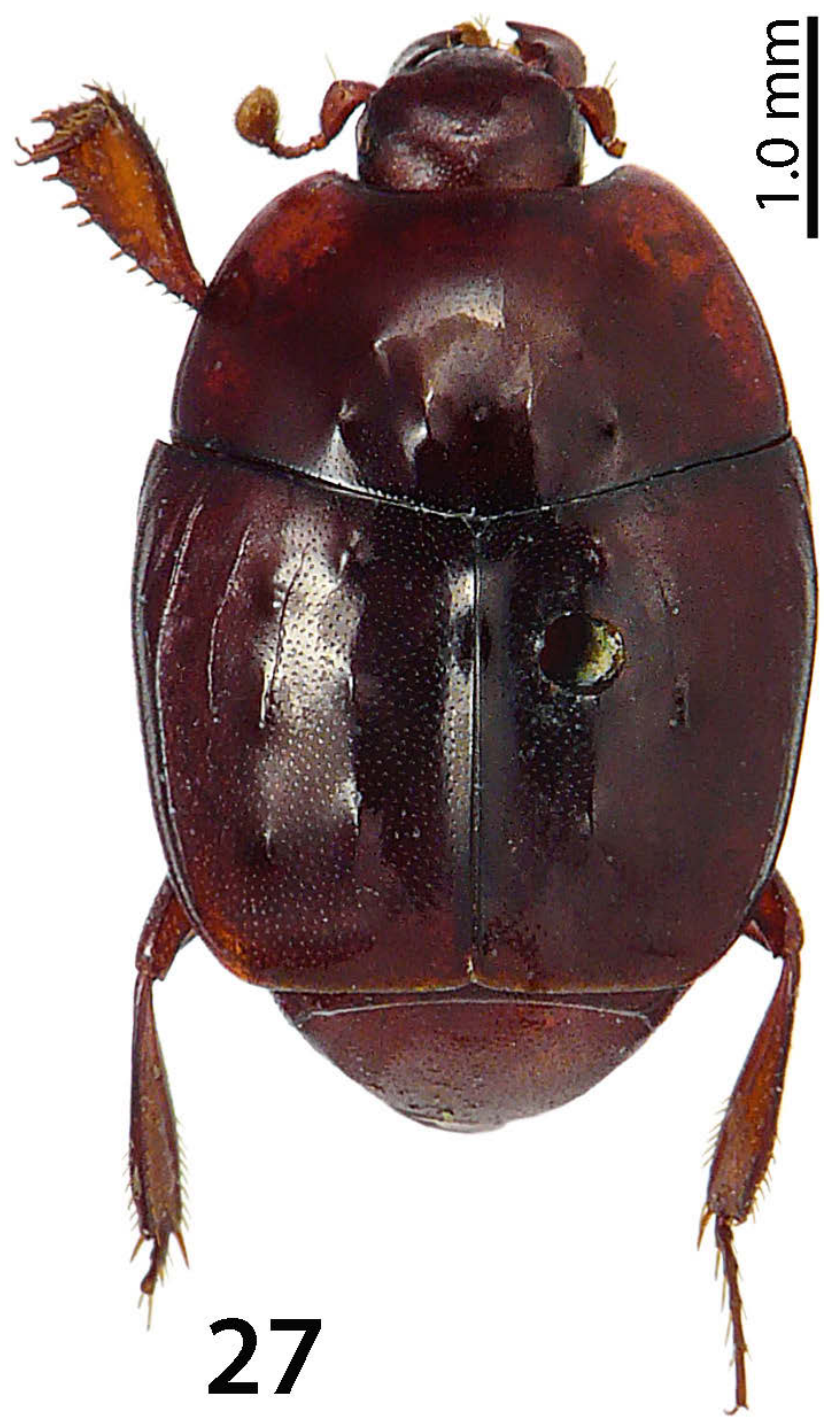

Fig. 27. Phoxonotus lectus, holotype male, dorsal view.

stria is indistinct): $1^{\text {st }}$ the longest, almost complete; $2^{\text {nd }}$ stria present on basal third (roughly); $3^{\text {rd }}$ stria of approximately identical length as $2^{\text {nd }}$, along its course running over two distinct tubercles: a smaller, round one basally, and a larger, elongate one apically; another, even smaller than basalmost round tubercle situated under large elongate median one. Fourth dorsal elytral stria absent; in its stead there are three approximately evenly-spaced prominent tubercles: basalmost one the smallest, median and apicalmost larger, approximately of the same size. Sutural elytral stria absent; surface between elytral suture and tubercles distinctly concave, forming a shallow furrow. Elytral suture elevated, elevation forming before scutellum an indistinct tubercle.

Propygidium (Fig. 5) half-covered by elytra, broad, covered with sparse fine punctures; pygidium (Fig. 5) triangular, covered with regular round punctures separated by approximately several times their diameter becoming smaller, finer and sparser apically.

Prosternum (Fig. 6): base of prosternum acutely inwardly emarginated to accommodate anteriorly projecting mesoventrite; prosternal process on basal $2 / 3$ evenly to only slightly elevated, abruptly elevated and broadened on ante- 


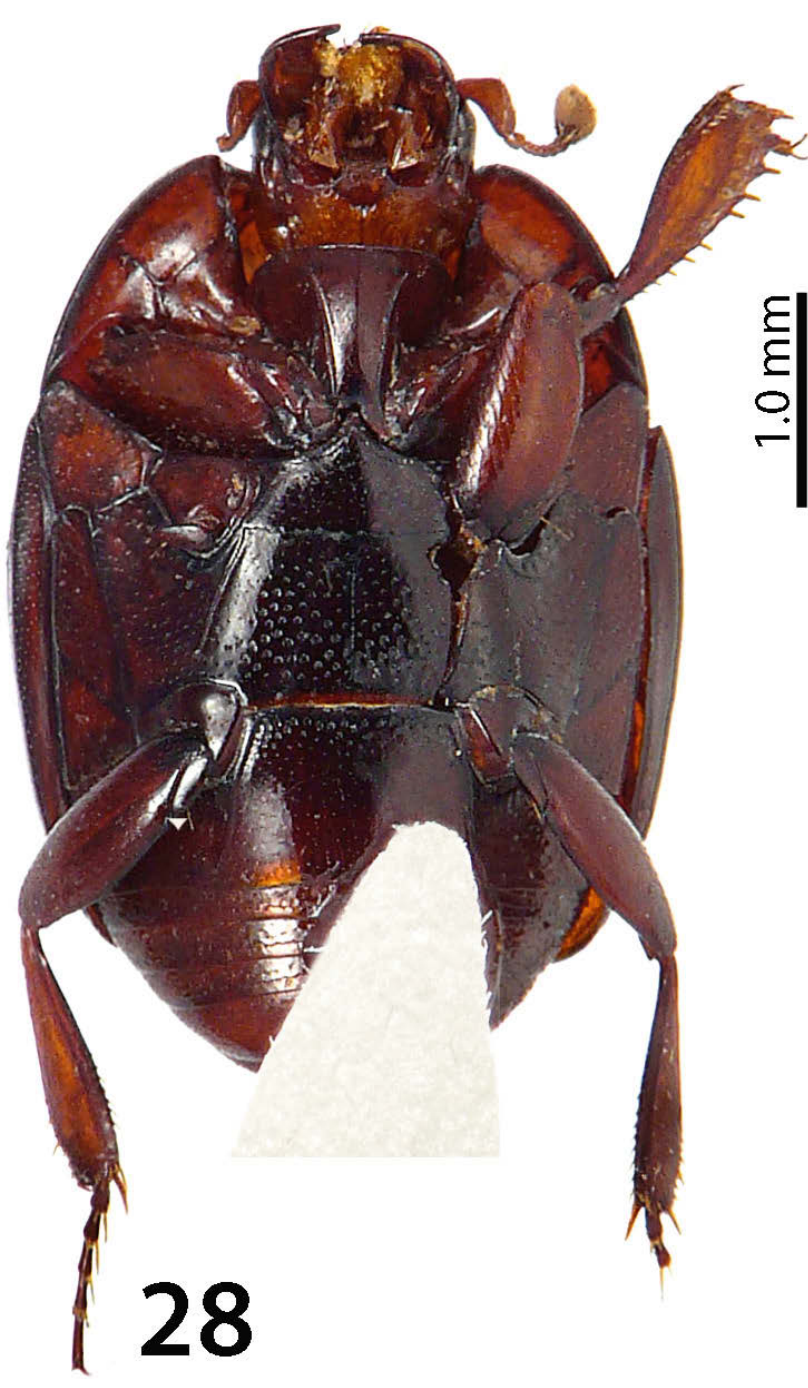

Fig. 28. Phoxonotus lectus, holotype male, ventral view.

rior third. Carinal prosternal striae carinate, subparallel to slightly divergent on basal $2 / 3$, on apical third widely divergent and united anteriorly under large round loop; surface between carinal prosternal striae finely punctuate. Lateral prosternal striae carinate, slightly convergent anteriorly, attaining carinal prosternal striae approximately at the point where the latter widely diverge anteriorly. Lateral costa of antennal groove terminates anterior to procoxa and does not reach prosternal process; antennal cavity for accommodating antennal club (while head is retracted) situated on lateral portion of anterior margin of composite ventral plate between tergopleural suture and procoxa, forming a well-defined, albeit shallow semiglobular impression; its base marked by a distinct ridge.

Mesoventrite (Fig. 7) subtrapezoid, anteriorly projecting and entering basal margin of prosternum, lateral mesoventral stria complete, thin, interrupted in anterolateral angles; disc of mesoventrite with variously-sized punctures separated by up to several times their diameter; meso-metaventral sutural stria present, thin, serrate, in form of interconnected punctures.

Metaventrite: disc of metaventrite with median longitudinal depression that is more prominent in male, surface

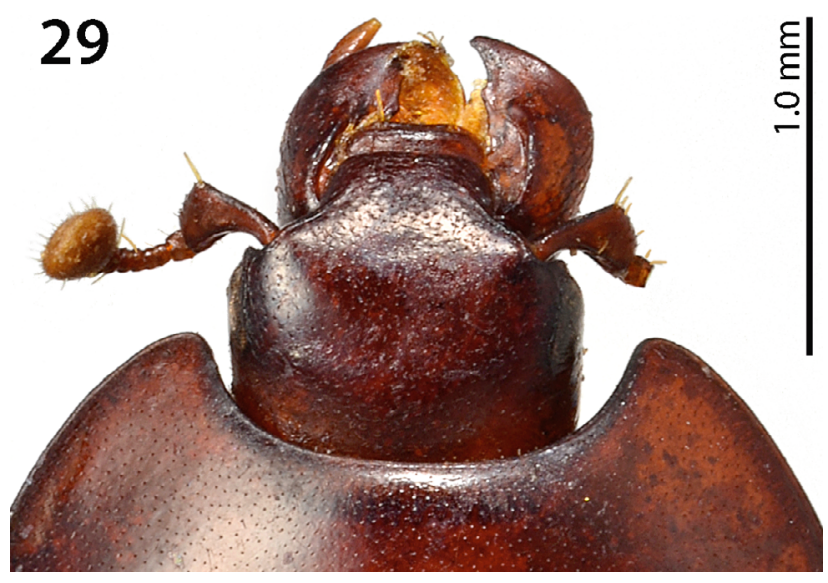

Fig. 29. Phoxonotus lectus, holotype male, head, dorsal view.

around median longitudinal line covered with large and deep dense punctures separated by approximately their diameter; punctures become smaller and sparser anterolaterad; marginal metaventral stria almost straight, carinate, stopping short of metacoxa. Lateral disc on metaventrite (Fig. 8) with shallow confluent ellipsoid punctures; anepisternum and metepisternum covered with identical punctation.

First visible abdominal sternite completely striate laterally, apices of striae slightly curved outwardly; disc with scattered microscopic punctation more prominent along base and lateral margins.

Legs: protibia (Fig. 9) flattened and widened, on outer margin four distinct triangular teeth diminishing in size in proximal direction topped by prominent denticle followed by a row of 8-9 short denticles growing out from extremely low teeth diminishing in size in proximal direction; protarsal groove wide but shallow; setae of outer row very small, thin; setae of median row even shorter, microscopic; protibial stria vestigial, present only basally. Protibial spur long, prominent, growing out from near protarsal insertion. Apical margin of protibia with 3-4 short denticles; outer part of posterior surface of protibia (Fig. 10) with a single row of evenly-spaced short denticles; otherwise glabrous. Posterior protibial stria complete, terminating in four inner posterior denticles; setae of inner margin of protibia double. Mesotibia (Fig. 11) on outer margin with a row of $15+$ denticles growing in size in proximal direction outer row of setae regular, shorter than denticles; posterior margin of mesotibia covered with short sparse setae not forming distinct rows; mesotibial spur long, prominent. Anterior margin of mesotibia with another row of tiny denticles; anterior mesotibial stria complete, terminating in two inner anterior denticles; setae of inner row strongly sclerotized, present only on proximal half of mesotibia (Fig. 12). Metatibia (Fig. 13) with on outer margin three short thin denticles separated from another two, longer denticles situated near apex of metatibia. Setae of outer row thin, regularly-spaced, growing in size apically; setae of median row much shorter. Metatibial spur long, prominent; anterior margin of metatibia with a single row of tiny denticles; anterior metatibial stria complete, terminating in three inner anterior denticles. 


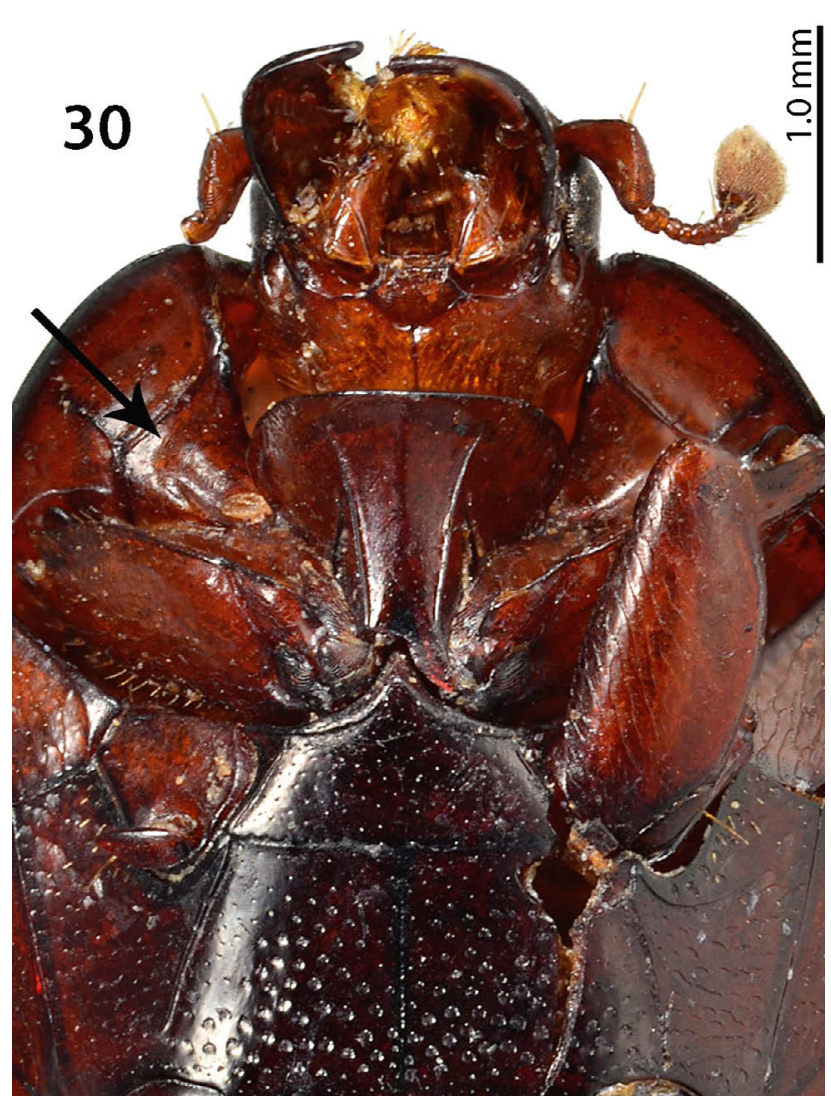

Fig. 30. Phoxonotus lectus, holotype male, prosternum, meso and metaventrite; black arrow indicates position of an antennal cavity on prothorax.

Male genitalia: eighth sternite (Fig. 17) separated medially; apically with additional subquadrate sclerite furnished with several inconspicuous setae; eighth tergite widely inwardly arcuate basally, only slightly inwardly arcuate apically; eighth sternite and tergite not fused laterally (Fig. 19). Ninth and tenth tergites (Figs 20-21) typical for the subfamily; spiculum gastrale (Fig. 22): basal end ("tail") spoon-like, outwardly arcuate, apical end ("head") gradually dilated from approximately halfway along its length; laterally with downwardly turned "horns". Aedeagus (Fig. 24) tube-like, parameres fused along their basal half, apex of aedeagus pointed, basal piece dilated basally, rather short, its length : length of parameres approximately $1: 4$; aedeagus strongly curved ventrad (Fig. 25).

Biology. Beetles of the "Suriname series" were collected in detritus-rooms of Atta cephalotes L. and A. sexdens L. by D.C. Geijskes in 1938 in northern Suriname. According to Kanaar (1997) the detritus-rooms of the nests of both Atta species are situated on the periphery of the system of galleries in the nests. In addition to exhausted material from the fungus gardens of the ants, these rooms contain numerous dead ants (Kanaar, 1997). It is likely that both the larvae and adults of Phoxonotus feed on some arthropods associated with the detritus-rooms of Atta ants. One specimen (from Mato Grosso, Brazil) was collected using a flight intercept trap.

Distribution. Known from French Guyana, Suriname and Brazil: Mato Grosso and Pará (Fig. 74).
Differential diagnosis. This species differs from the very similar $P$. lectus by the denser punctuation of the mesoventrite and a thinner aedeagus. See also differential diagnosis of P. lectus. From the newly described P. parvotuberculatus, $P$. tuberculatus differs in the presence of a second row of tubercles on the pronotum, and more prominent and numerous elytral tubercles.

Remarks. Marseul's original description of the genus and species (1862: 35-38) in general agrees with the present redescription based on specimens from French Guyana and Suriname, with the following discrepancies: (a) Marseul writes that the mandibles lack a subapical tooth ("sans dent interne"). This was not observed as there is a short and blunt subapical tooth present on the mandibles of the specimens studied (Fig. 14); (b) antennal club formed by four distinct segments (Marseul, 1862: 36; Fig. 1b; Fig. 26 in the present paper; "massue...de quatre articles peu distincts"...); this again was not observed, there were no traces of intersegmental sutures on the antennal clubs of specimens studied (Fig. 3); (c) feebly acute anterior pronotal angles of Marseul (1862: 36 “...les angles arrondis, peu saillants..."), whereas, the anterior angles of the pronotum are rather prominent and acute in the specimens studied (Fig. 1); (d) Marseul's four dorsal elytral striae (1862: 36: "...quatre stries dorsales fines, obliques..."; in his Fig. 1 , however, this fourth stria is not figured), whereas, the fourth stria is always lacking and represented only by a row of tubercles in the specimens studied (Fig. 1); (e) Marseul's misinterpretation of the subhumeral striae. Marseul (1862: 36) writes "...deux subhumérales parallèles sur le bord lateral...", whereas, in my opinion one of the two striae is the true inner subhumeral and the second the marginal elytral stria; (f) Marseul (1862: 36, 38, Fig. 1a) mentions carinal prosternal striae being almost parallel and then widely divergent anteriorly. In the specimens studied, the carinal prosternal striae are never completely parallel (e.g., Fig. 6), they are more or less divergent along their course before they become widely divergent and form a rounded loop apically.

Lewis (1907) described P. suturalis from Obidos River, Amazonia (actually situated in Pará State of modern Brazil). He distinguished this newly described species from all other congeners by the presence of "the sutural tubercle on the dorsum". However, all specimens of $P$. tuberculatus examined from French Guyana and Suriname also have this sutural tubercle. Marseul (1862) in his description of $P$. tuberculatus does not mention this "sutural tubercle", which he probably overlooked. As the original Marseul's type specimen(s) of $P$. tuberculatus cannot be located in the collection of MNHN, it is assumed that the specimens examined here from French Guyana and Suriname are conspecific with $P$. tuberculatus (as they agree with the description in most morphological characters) and thus this "sutural tubercle" is present in P. tuberculatus. The type locality of $P$. suturalis, Obidos city on the Amazon River, lies south of the "Guyanas", in the Amazon River basin; both French Guyana and Suriname are likewise part of this vast ecosystem. 

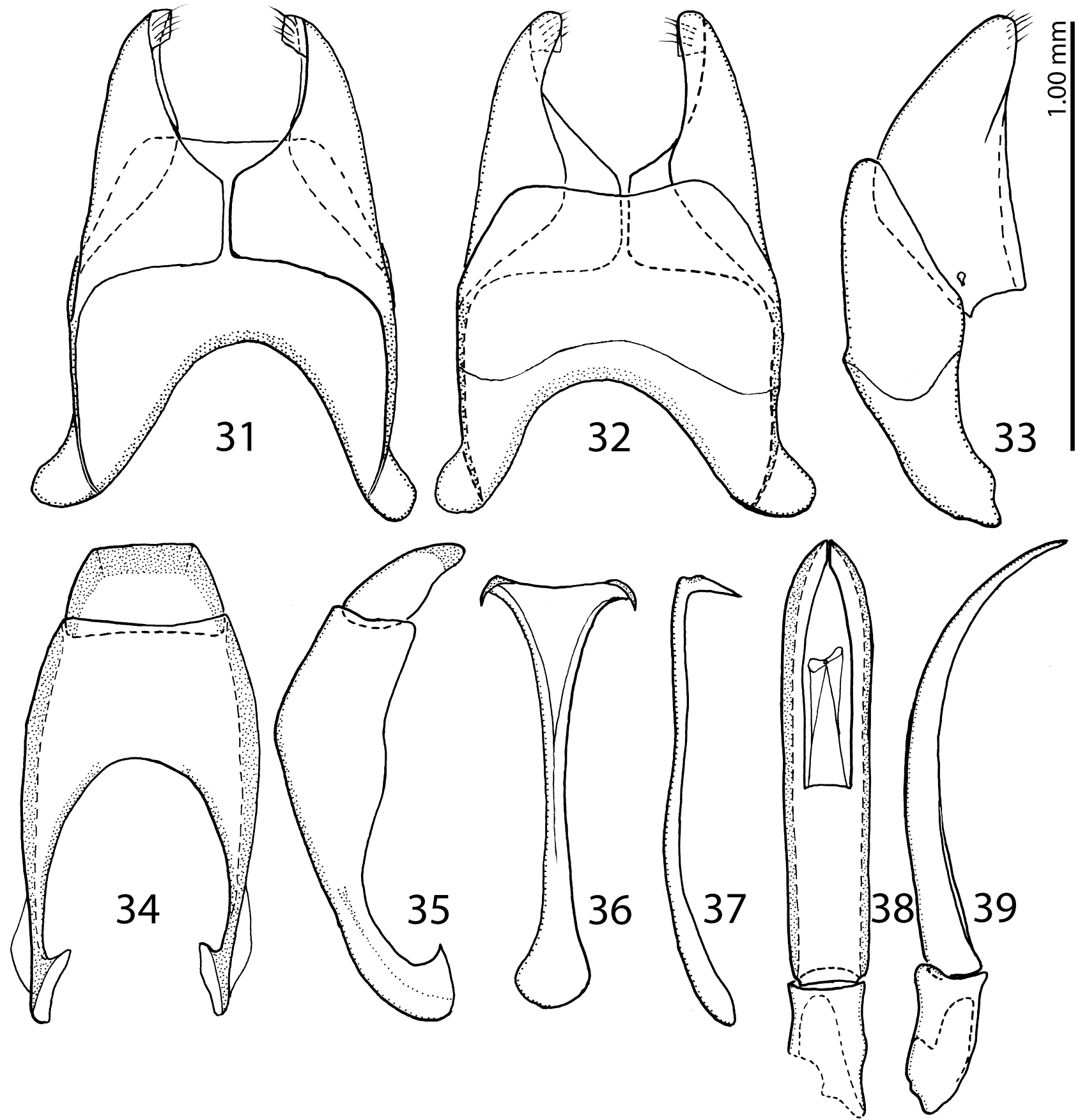

Figs 31-39: Phoxonotus lectus, holotype male. 31 - eighth sternite and tergite, ventral view; 32 - ditto, dorsal view; 33 - ditto, lateral view; 34 - ninth and tenth tergites, dorsal view; 35 - ditto, lateral view; 36 - spiculum gastrale, ventral view; 37 - ditto, lateral view; 38 aedeagus, dorsal view; 39 - ditto, lateral view.

\section{Phoxonotus (Phoxonotus) lectus Lewis, 1902}

(Figs 27-39)

Phoxonotus lectus Lewis, 1902: 269; Bickhardt (1916): 109; Mazur (1984): 114; Mazur (1997): 217; Mazur (2011): 178.

Type material examined. Holotype, $\widehat{\partial}$, mounted on tip of a triangular mounting point, right antenna reduced to scape and pedicel, other segments missing, right protibia and mesotibia missing, left mesotibia broken off, glued to the same mounting point as the specimen (devoid of tarsal segments 2-5), segments 3-5 of left metatarsus missing, with extracted and dismembered male genitalia glued onto the same triangular point as the specimen with the following labels: " $O$ " (printed); followed by: "E. Peru" (printed); followed by: "Type" (red-margined round label); followed by: "Phoxonotus / lectus / Type / Lewis" (written) (BMNH).

Note. The original description does not specify the number of type specimens, but does not indicate that more than one existed. Only one type specimen was found in BMNH, which is thus assumed to be the holotype.

Additional material examined. None.

Diagnostic description. Because of the overall similarity of Phoxonotus lectus with P. tuberculatus, only a very brief diagnostic description the former species is provided, which outlines the differences between the two taxa. Body (Figs 27, 28) $\mathrm{PEL}=3.25 \mathrm{~mm}$; $\mathrm{APW}=1.25 \mathrm{~mm}$; $\mathrm{PPW}=$ 


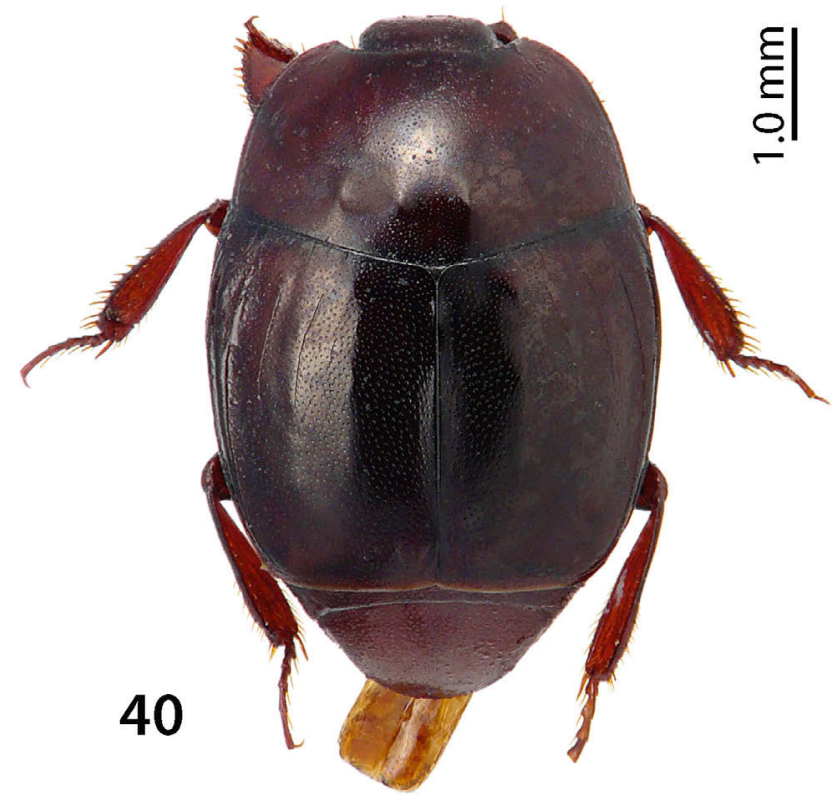

Fig. 40. Phoxonotus parvotuberculatus sp. n., paratype female, habitus, dorsal view.

$2.50 \mathrm{~mm} ; \mathrm{EW}=2.65 \mathrm{~mm} ; \mathrm{EL}=2.00 \mathrm{~mm}$. General outlook (Figs 27, 28), head (Fig. 29) and prosternum (Fig. 30) almost identical to $P$. tuberculatus. The two species differ chiefly in the sparser and finer punctuation on the mesoventrite (compare Figs 7 and 30) and slightly thicker aedeagus (compare Figs 24 and 38).
Differential diagnosis. $P$. lectus differs from $P$. tuberculatus mainly in its more dilated aedeagus and finer and sparser punctation on the mesoventrite, and from P. parvotuberculatus in the same characters.

Biology. Unknown, presumably similar to congeners.

Distribution. Eastern Peru, without further specifications (Fig. 74).

Remarks. Lewis (1879: 61) in his description of P. fryi mentions: "I have a specimen of this genus from Peru, which is evidently $P$. tuberculatus Mars...". It is possible that this specimen was later designated as the type specimen of $P$. lectus, after Lewis changed his mind. Lewis (1902: 269) in his description of $P$. lectus compares it with Marseul's $P$. tuberculatus, citing a few differences, and stating that "...the striae on the latter [= on the elytra of P. lectus] are fine, and correspond with those figured for P. tuberculatus, Mars. ..."; and "...the tibiae are formed like those figured by Marseul for P. tuberculatus.". Lewis (1902) writes that the "form of the prosternal striae and the punctation on sternal plates readily distinguish this species from $P$. tuberculatus". In the type specimen studied, neither the form of the prosternal striae nor the punctation on the sternal plates distinguishes this species from $P$. tuberculatus; on the other hand, what does give some support to the validity of this species is a slightly more dilated aedeagus and sparser punctuation on the mesoventrite (these characters were not mentioned by Lewis). Inasmuch as I was not able to locate Marseul's species in the collection of

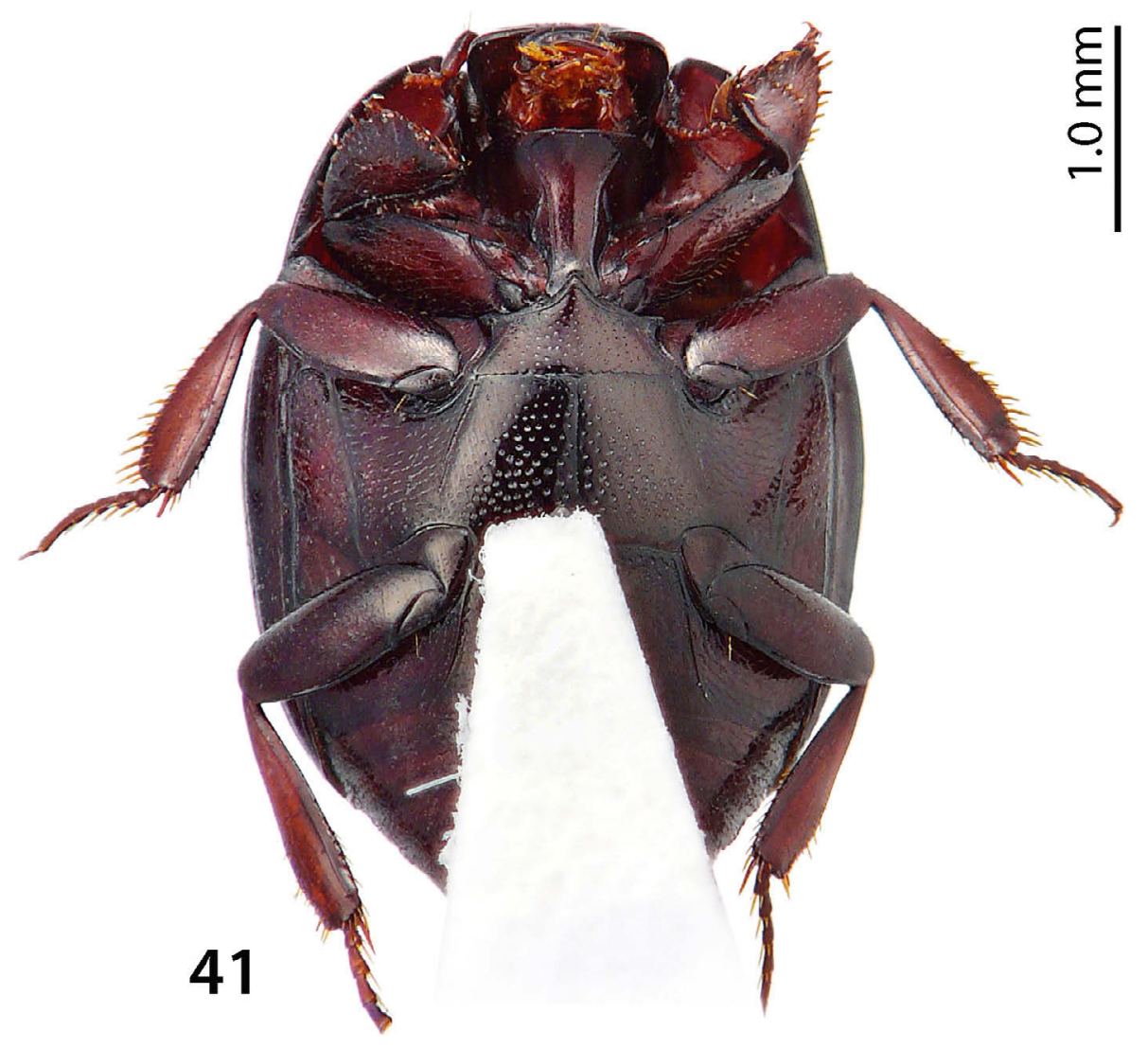

Fig. 41. Phoxonotus parvotuberculatus sp. n., paratype female, habitus, ventral view. 

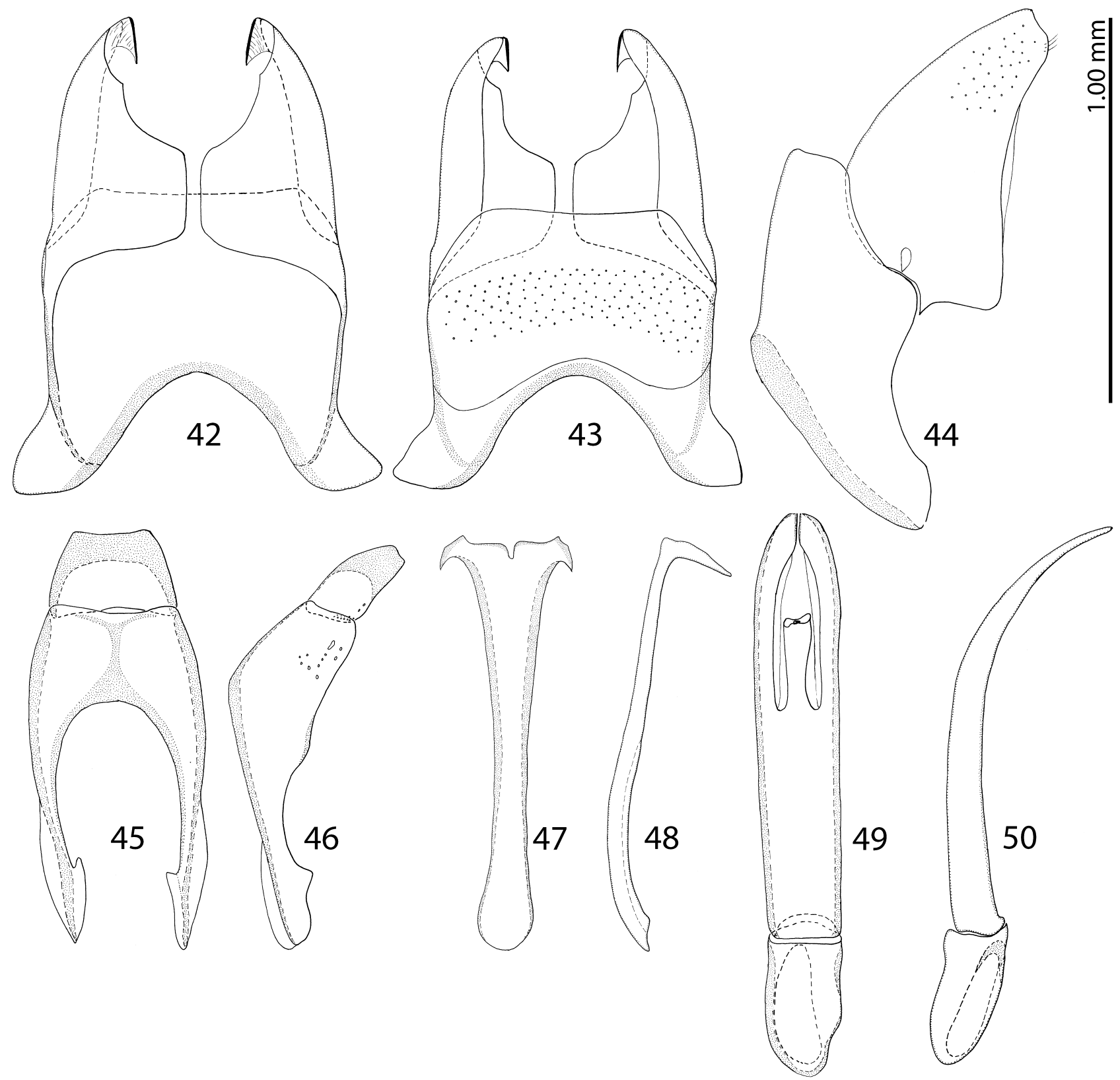

Figs 42-50. Phoxonotus parvotuberculatus sp. n., holotype male. 42 - eighth sternite and tergite, ventral view; 43 - ditto, dorsal view; 44 - ditto, lateral view; 45 - ninth and tenth tergites, dorsal view; 46 - ditto, lateral view; 47 - spiculum gastrale, ventral view; 48 - ditto, lateral view; 49 - aedeagus, dorsal view; 50 - ditto, lateral view.

MNHN, a direct comparison with the type specimens, let alone an examination of the male genitalia, was not possible. For these reasons I am hesitant to synonymize P. lectus with $P$. tuberculatus and opt for keeping its current taxonomic status pending discoveries of specimens at localities between the Guyanas and Peruvian Amazonia.

Phoxonotus (Phoxonotus) parvotuberculatus sp. n. (Figs 40-50)

ZooBank taxon LSID:

FE8591D6-B19F-4FC3-808C-8820C70B0866

Type material. COSTA RICA: Holotype, $\hat{\jmath}$, mounted on a mounting point, with male genitalia mounted on a separate card under the specimen, left protibia missing, three tarsomeres of right mesotibia and claws of right metatarsus missing, with the following labels: "Cervantes, alt. $1450 \mathrm{~m} /$ Cartago, COSTA
RICA / 8 April 1940 / L.A. Salas" (printed); followed by: "Processed \& Printed / from US NMNH dry vial / A.K. Tishechkin 2009"; followed: "Phoxonotus (Phoxonotus) / parvotuberculatus sp. n. / HOLOTYPE / Det. T. Lackner 2015" (red label, written) (USNM). Paratypes: $2 \hat{\jmath}+1 q$ with identical labels to the holotype (1ठ PT kept in CTL, other 2 in USNM). 1 , , with the following labels: " $\varnothing$ " (printed); followed by: "COSTA RICA: Heredia pr. / La Selva Biol. St. / $3 \mathrm{~km} \mathrm{~S} \mathrm{Pto.} \mathrm{Viejo} \mathrm{/} 10^{\circ} 26^{\prime} \mathrm{N}, 84^{\circ} 01^{\prime} \mathrm{W}$ ” (printed); followed by: "18.IV.1988 / H. A. Hespenheide" (printedwritten); followed by: "Phoxonotus / sp. / Det. M.S. Caterino 199" (printed-written); "Phoxonotus (Phoxonotus) / parvotuberculatus sp. n. / PARATYPE / Det. T. Lackner 2015" (red label, written) (MNCR). GUATEMALA: 2 specs., sex undetermined, both mounted on the tip of a mounting point, with the following labels: "GUAT. Finca San Rafael / Olimpo, Cuyotenango / Such. I. 21.1966 / J.M. Campbell 1700"' (printed-written), followed by: "Collected from large / detritus cavity of / Atta sp., 6-8' deep" 


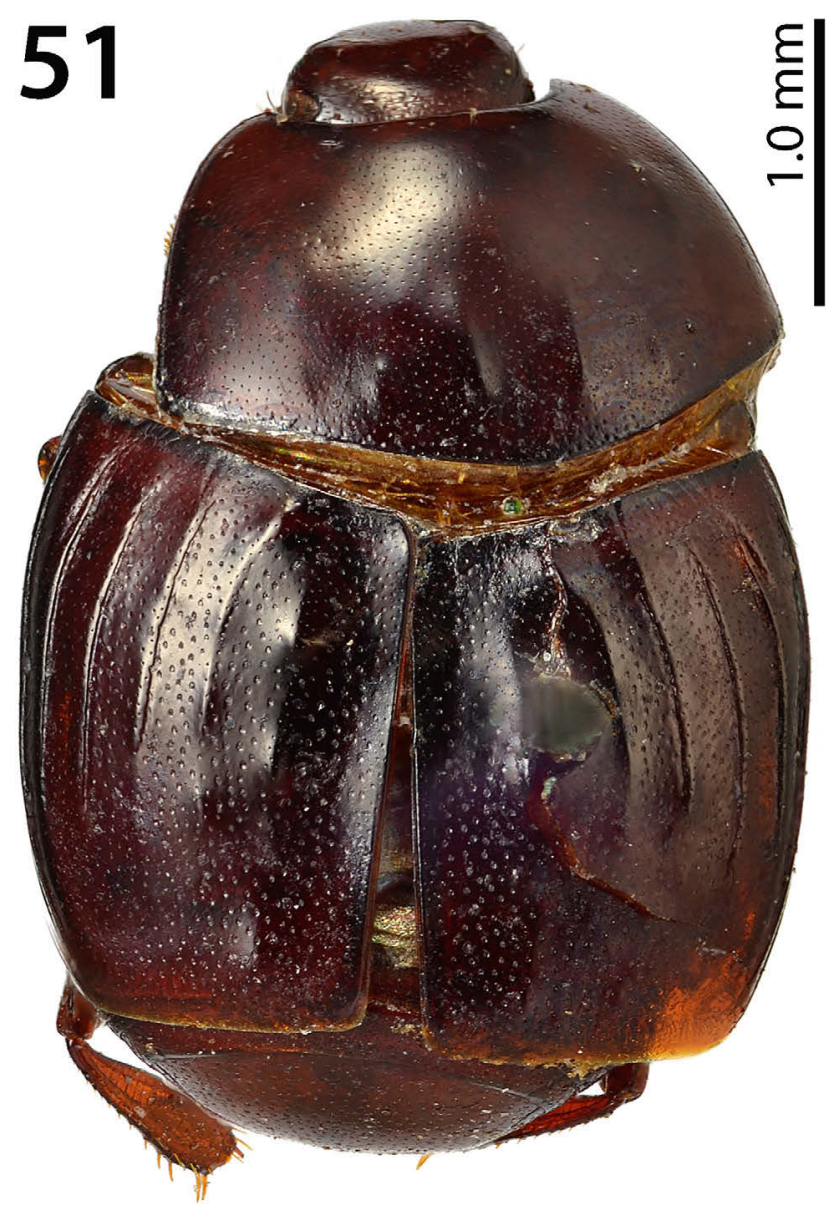

Fig. 51. Phoxonotus venustus, holotype male, dorsal view.

(printed), followed by: "Phoxonotus (Phoxonotus) / parvotuberculatus n.sp. / PARATYPE det. T. / Lackner 2015” (FMNH).

Type locality: Costa Rica, prov. Cartago, Cervantes, $1450 \mathrm{~m}$.

Diagnostic description. Body (Fig. 40) PEL = 4.00-4.10 $\mathrm{mm} ; \mathrm{APW}=1.20-1.25 \mathrm{~mm} ; \mathrm{PPW}=3.00-3.10 \mathrm{~mm} ; \mathrm{EW}=$ $3.20-3.25 \mathrm{~mm} ; \mathrm{EL}=2.50-2.55 \mathrm{~mm}$; oval, dorsally convex, ventrally flattened, cuticle castaneous, wholly punctuate; punctures more prominent on elytra and metaventrite than on rest of body. Body appendages castaneous.

Head: fronto-clypeal region faintly depressed, frontal disc with scattered microscopic punctures, frontal stria widely interrupted, prolonged onto clypeus; supraorbital stria indistinct; clypeus not margined anteriorly, disc of clypeus with very faint confluent punctures. Eyes rather small, inconspicuous from above. Antenna generally similar to that of $P$. tuberculatus; sensory structures on antenna not examined. Mandibles in general like those of $P$. tuberculatus. Labrum glabrous, subtrapezoidal; with large longitudinal median convexity followed by strongly depressed anterior third; a pair of large labral pits each with two unusually long, slender labral setae situated on boundary between the anterior third and longitudinal median convexity. Rest of mouthparts not examined.

Pronotum (Fig. 40) in general similar to that of P. tuberculatus, but marginal pronotal stria prolonged for a short distance along pronotal base; pronotal disc with a single row of faint tubercles situated medially on basal pronotal third: two inner tubercles more prominent than the two vague outer ones. Scutellum small and triangular.

Elytra widest across humeri, wholly punctuate, punctures separated by about their diameter. Elytral epipleuron finely microscopically punctuate, marginal epipleural stria fine, complete and carinate; marginal elytral stria carinate and complete; apical elytral stria absent; inner subhumeral stria long, carinate and complete, subparallel to marginal elytral stria, for short distance continuous along elytral apex. Oblique humeral stria faint; elytral disc with three distinct dorsal elytral striae: $1^{\text {st }}$ the longest, almost complete, costate on apical two-thirds; $2^{\text {nd }}$ and $3^{\text {rd }}$ dorsal elytral striae shortened basally, stopping short of elytral half. Base of third elytral stria marked by a small vague tubercle; fourth dorsal elytral stria absent, its imaginary base marked by a prominent round tubercle; another, very faint elongate tubercle present at approximately half way along elytra; surface between these two tubercles and elytral suture depressed; elytral suture elevated.

Propygidium almost entirely covered by elytra; pygidium triangular, covered with regular round punctures separated by approximately their or several times their diameter becoming smaller, finer and sparser apically.

Prosternum (Fig. 41): structure of prosternum overall similar to that of $P$. tuberculatus; lateral prosternal striae carinate; structure of antennal cavity is similar to that of $P$. tuberculatus.

Mesoventrite (Fig. 41) in general similar to that of $P$. tuberculatus, but disc of mesoventrite with faint scattered tiny punctuation, punctures separated by their own diameter; meso-metaventral sutural stria faint, thin, in form of interconnected punctures.

Metaventrite (Fig. 41): disc of metaventrite in general overall similar to that of $P$. tuberculatus; marginal metaventral stria almost straight, carinate, stopping short of metacoxa; lateral disc on metaventrite as in $P$. tuberculatus.

First visible abdominal sternite as in $P$. tuberculatus.

Legs: very similar to those of $P$. tuberculatus.

Male genitalia (Figs 42-50). Generally quite similar to the type of the genus, $P$. tuberculatus, differing from it chiefly in having an apically notched spiculum gastrale (compare Figs 22 and 47) and an aedeagus that is slightly broader apically (compare Figs 24 and 49).

Biology. The three Guatemalan specimens were collected from a large detritus cavity of Atta sp., 6-8 feet (=1.8$2.4 \mathrm{~m}$ ) deep; biological data on Costa Rican specimens are lacking.

Distribution. Known only from Guatemala and Costa Rica (Fig. 74).

Differential diagnosis. $P$. parvotuberculatus is in most external morphological characters similar to both $P$. tuberculatus and P. lectus, but differs from both of them in the absence of a second row of tubercles on the pronotum and much less developed elytral tubercles.

Etymology. The specific epithet of this species refers to the small tubercles on the dorsum. It is composed of the Latin words "parvus", meaning "small", and "tuberculatus", meaning "tuberculate", or furnished with bolts, tubercles. 

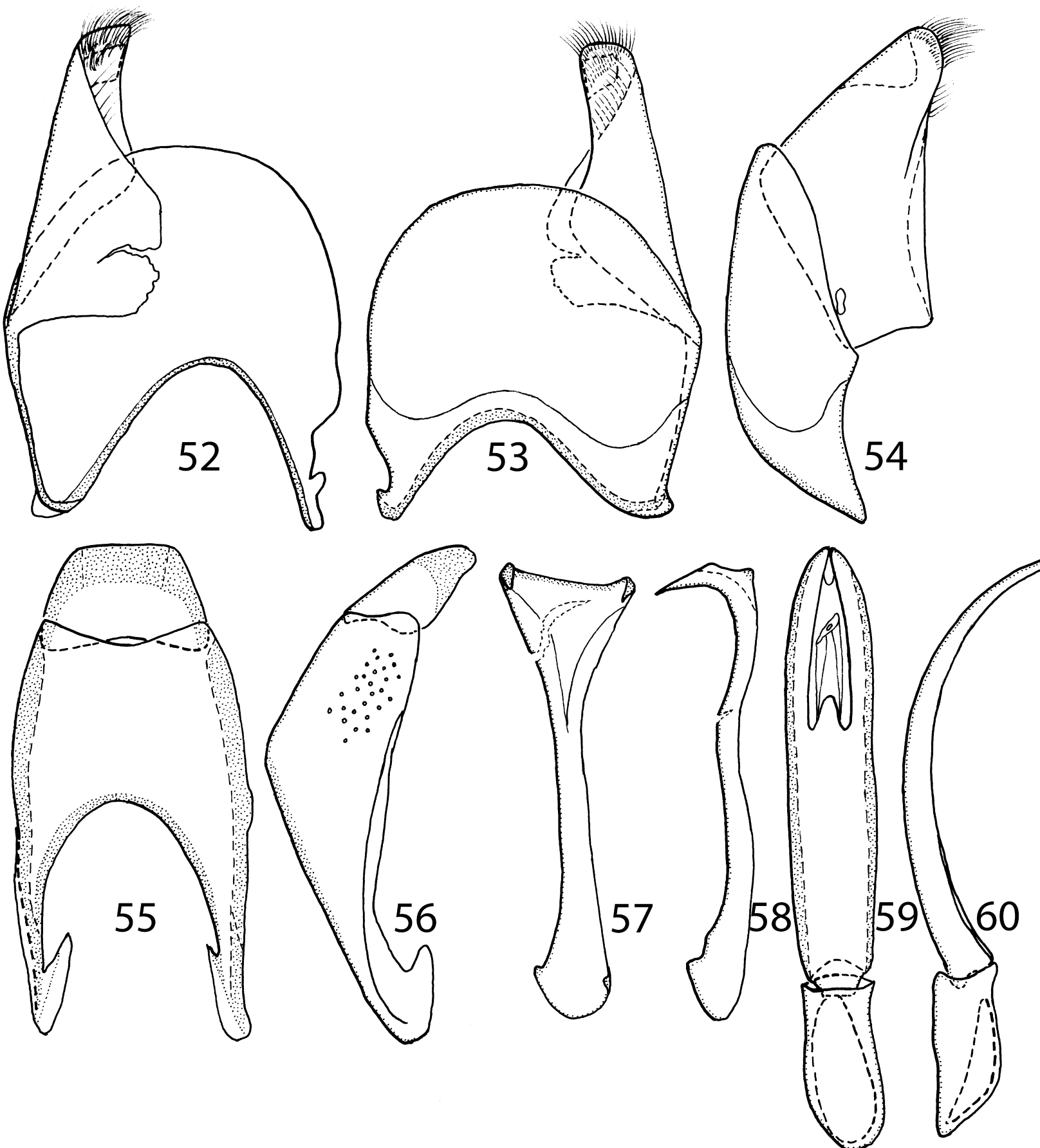

Figs 52-60: Phoxonotus venustus, holotype male. 52 -eighth sternite and tergite, ventral view; 53 - ditto, dorsal view; 54 - ditto, lateral view; 55 - ninth and tenth tergites, dorsal view; 56 - ditto, lateral view; 57 - spiculum gastrale, ventral view; 58 - ditto, lateral view; 59 aedeagus, dorsal view; 60 - ditto, lateral view.

\section{Subgenus Alienosternus subgen. $\mathbf{n}$.}

ZooBank taxon LSID:

B08048A9-791E-449E-A6CF-24EE5C06D741

Type species. Saprinus venustus Erichson, 1834.

Diagnosis. Antennal cavity typically Saprininae-like (see, e.g., Lackner, 2010: Figs 148-149) formed by the prosternal process and outer lateral costa of antennal groove (Fig. 64); carinal prosternal striae angulate apically, not forming a rounded loop (Fig. 64). Between the row of tubercles indicating the course of the fourth dorsal elytral stria and elytral suture there is another row of four tubercles.

Differential diagnosis. See Differential diagnosis for Phoxonotus s. str.

Biology. See biology of Phoxonotus s. 1.

Distribution. Brazil: Bahia and Rio de Janeiro states (Fig. 74).

Etymology. Subgeneric name is formed by the combination of the Latin words "alienus", meaning "strange, weird" and substantive "sternum". Gender masculine. 


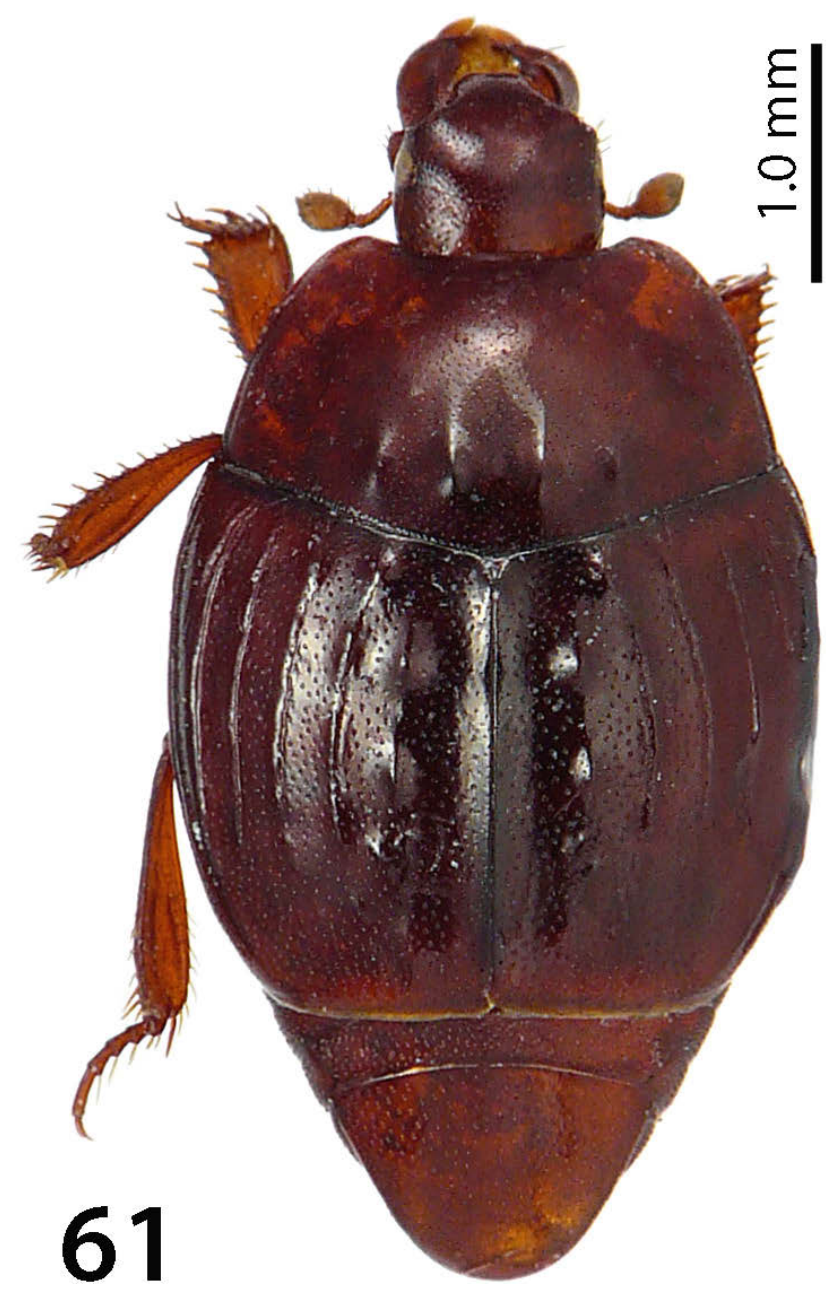

Fig. 61. Phoxonotus fryi, lectotype female, dorsal view.

\section{Phoxonotus (Alienosternus) venustus (Erichson, 1834)}

(Figs 51-60)

Saprinus venustus Erichson, 1834: 189.

Phoxonotus venustus: Lewis: 1886: 280; Bickhardt, 1916: 109; Mazur (1984): 114; Mazur (1997): 217; Mazur (2011): 178.

Type material examined. Holotype, $\hat{\delta}$, side-mounted on a triangular mounting point, left protarsus and mesotarsus missing, both metatarsi missing, with male genitalia extracted, dismembered and glued to the same mounting point as the type specimen, with the following labels: "venustus / Bahia Freir." (green, blackmargined label, written); followed by: "Phoxonotus" (written); followed by: "49179" (printed in bold font); followed by: "Hist. - Coll. (Coleoptera) / Nr. 49179 / Saprinus venustus Er. x / Bahia Freir / Zool. Mus. Berlin” (green, black-margined printed label) (ZMHB).

Note. The original description does not specify the number of type specimens, but does not indicate that more than one existed. Only one type specimen was found in ZMHB, which is thus assumed to be the holotype.

Additional material examined. None.

Diagnostic description. Body (Fig. 51) PEL = $3.00 \mathrm{~mm}$; $\mathrm{APW}=1.10 \mathrm{~mm}$; $\mathrm{PPW}=2.20 \mathrm{~mm}, \mathrm{EW}=2.55 \mathrm{~mm}$; $\mathrm{EL}=$ $1.85 \mathrm{~mm}$. Pronotum: base with one row of four tubercles: two inner ones elongate and about twice the size of outer

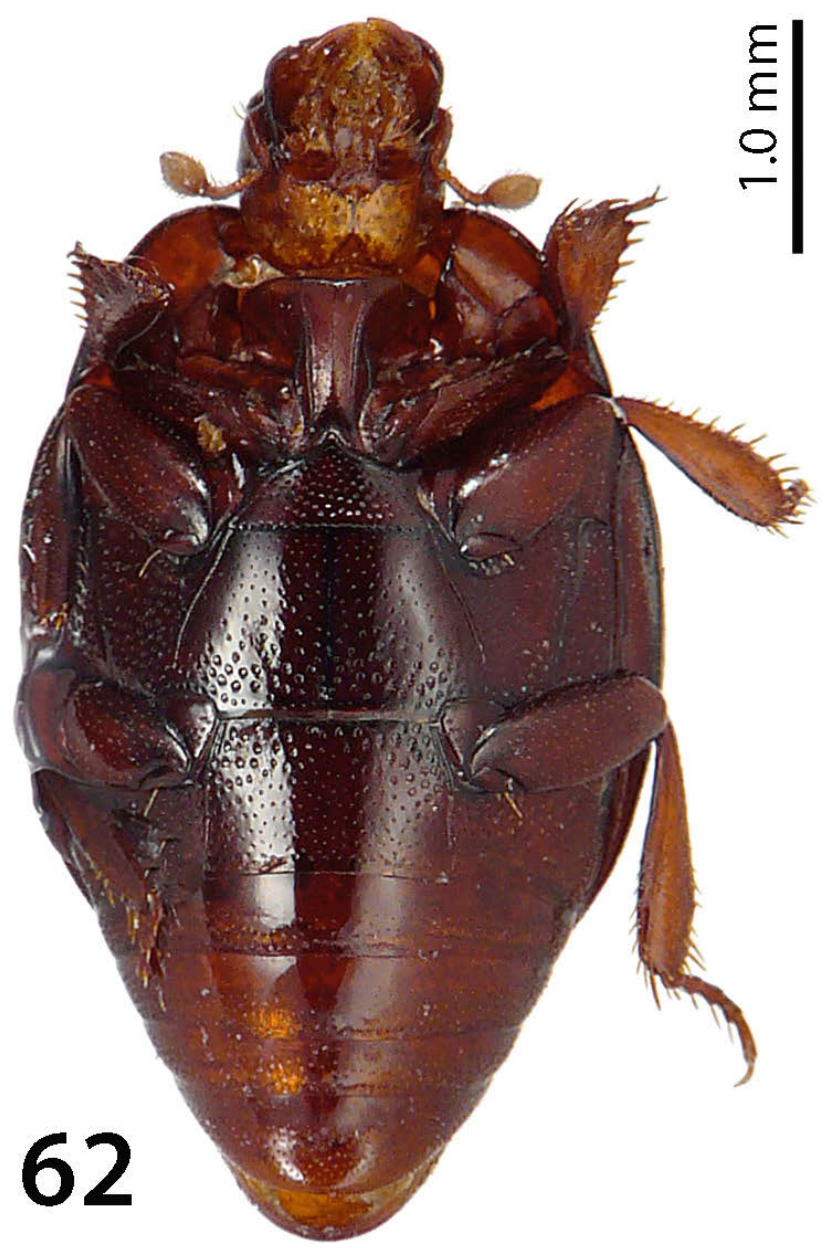

Fig. 62. Phoxonotus fryi, lectotype female, ventral view.

ones; two extremely vague, obsolete and low tubercles present in an anterad basal row, observable only in lateral view and under direct light. Inner subhumeral stria short, not reaching elytral apex; first and second dorsal elytral striae shortened apically, reaching approximately $2 / 3$ along elytral length; third dorsal elytral stria stopping approximately midway along elytra, fourth dorsal elytral stria absent, indicated by a row of three elongate vague tubercles. Another row of four prominent, evenly-spaced tubercles present between elytral suture and row indicating fourth dorsal elytral stria. Elytral suture elevated; vague tubercle situated anterad of scutellum absent. Carinal prosternal striae progressively divergent anteriorly, apically angulate, not forming a distinct rounded loop; outer lateral costa of antennal groove terminates before procoxa, antennal cavity formed by prosternal process and partially enclosed by procoxa on its basal part. Male metaventrite without median longitudinal line or depression. Male genitalia: eighth sternite (Fig. 52) apically with a dense brush of setae; eighth tergite (Fig. 53) apically outwardly arcuate; ninth tergite (Fig. 55) apically inwardly arcuate; tenth tergite (Fig. 55) basally inwardly arcuate. Spiculum gastrale (Fig. 57) triangularly dilated apically without prominent "horns", its base outwardly arcuate, not spoon-like. Aedeagus (Figs 59-60) tube-like, similar to that of congeners. 


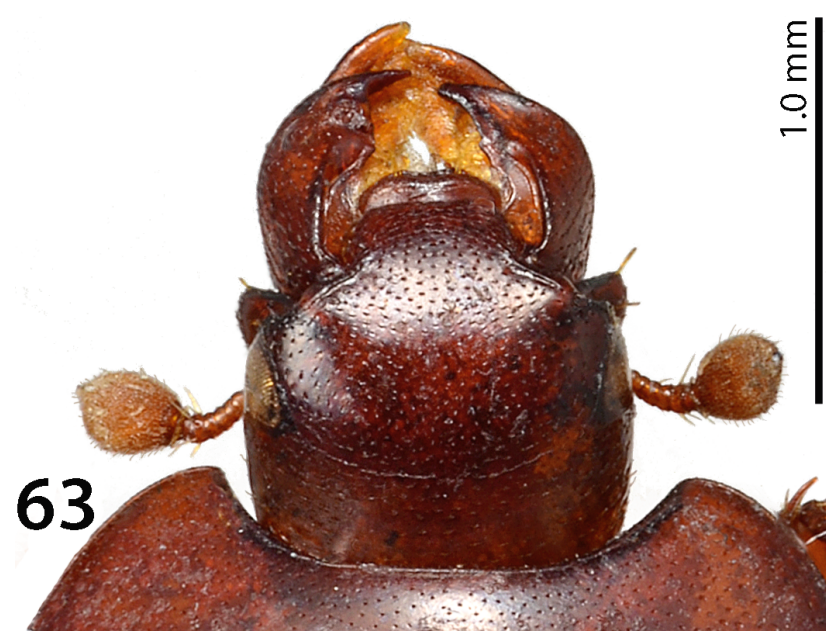

Fig. 63. Phoxonotus fryi, lectotype female, head, dorsal view.

Differential diagnosis. Most similar to $P$. fryi, differing from it mainly by the shape of the spiculum gastrale (compare Figs 57 and 70).

Biology. Unknown, presumably similar to congeners.

Distribution. Known only from the holotype, collected in the Bahia state, Brazil (Fig. 74).

Remarks. This species may be synonymous with $P$. fryi, which is also known from Bahia. Since the structure of the "head" of the spiculum gastrale in these two species differs I am hesitant to synonymize the two, pending the discovery of further specimens from the localities between Rio de Janeiro and Bahia state, Brazil.

\section{Phoxonotus (Alienosternus) fryi Lewis, 1879}

(Figs 61-73)

Phoxonotus fryi Lewis 1879: 61; Lewis (1902): 270; Bickhardt (1916): 109; Reichensperger (1935): 28; Mazur (1984): 114; Mazur (1997): 217; Mazur (2011): 178.

Type material examined. Lectotype, + , designated herein, side-mounted on a triangular mounting point, penultimate and ultimate left meso- and right metatarsomeres broken off, with the following labels: "O" (printed); followed by: "Fry / RioJan" (written); followed by: "Type" (red-margined, round label); followed by: "Phoxonotus / Fryi / Type / Lewis" (written); followed by: "Phoxonotus fryi / Lewis, 1879 / LECTOTYPE / des. T. Lackner 2015" (red label, written) (BMNH). Paralectotype, ㅇ, sidemounted on a triangular mounting card, both protarsi missing, abdomen separated from the rest of the body with disarticulated pygidium and extracted female genitalia all glued to the same mounting card as the specimen, with the following labels: "O" (printed); followed by: "Fry / RioJan" (written); followed by: "20842" (written); followed by: "Fry Coll. / 1905-100" (printed); followed by: "Type" (red-margined, round label); followed by: "Phoxonotus / fryi Lewis" (written); followed by: "Phoxonotus fryi / Lewis, 1879 / PARALECTOTYPE / des. T. Lackner 2015" (red label, written) (BMNH). The lectotype and paralectotype designation fixes the identity of this species.

Note. This species was described from "three or four specimens in Mr. Fry's collection all from Rio Janeiro district" (Lewis, 1879: 61). There are two specimens in BMNH with "Type" labels from "RioJan" [= Rio de Janeiro], designated here as a lectotype and paralectotype, respectively, and another specimen from Bahia originating also from Fry's collection that was labelled as

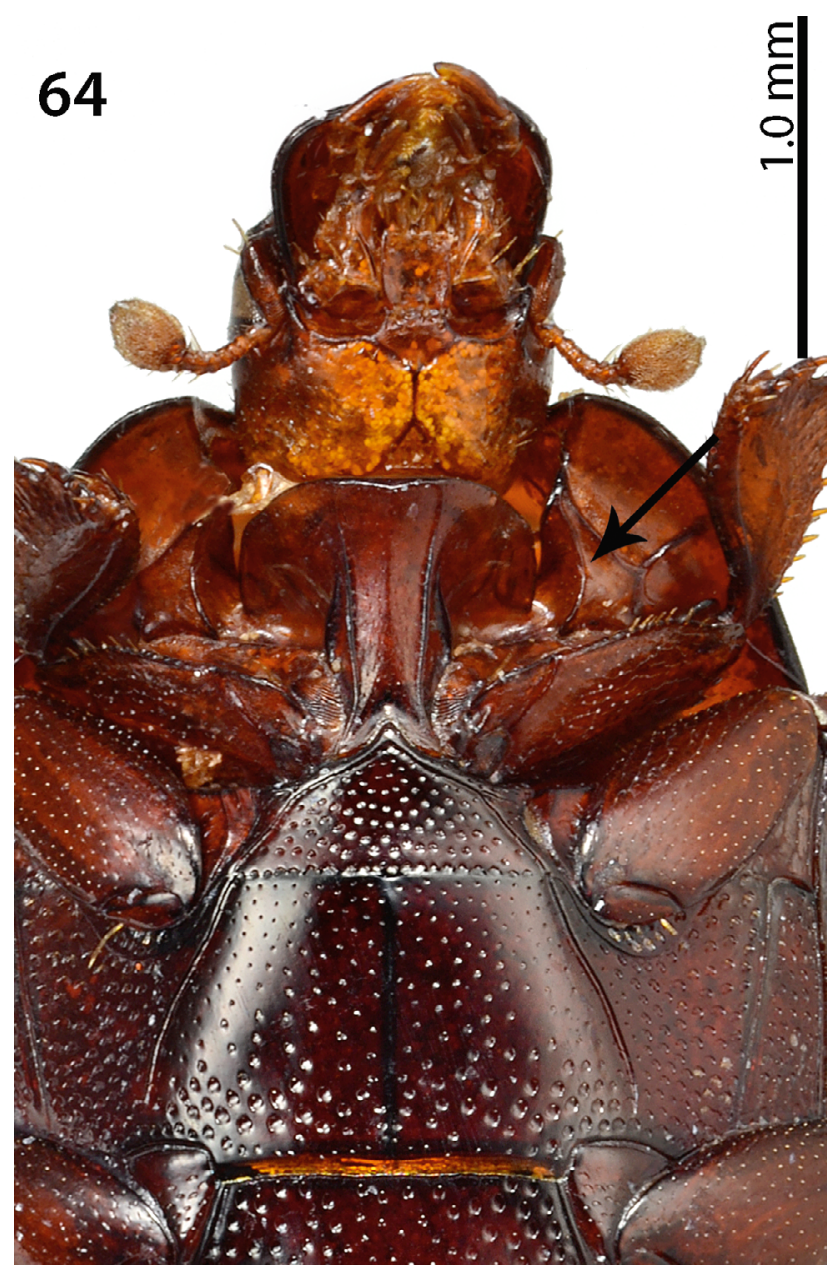

Fig. 64. Phoxonotus fryi, lectotype female, prosternum, meso and metaventrite; black arrow indicates the location of an antennal cavity on the prothorax.

P. fryi. Since this last specimen was not labelled as "type" and originates from a different locality than the two syntypes (Bahia vs Rio de Janeiro), only the two syntypes were labelled as the lectotype and paralectotype, respectively. Another specimen, found in the collection of FMNH, although labelled as "Paratype" by Lewis, and originating from Fry's collection, is from a locality that is different from the one given by Lewis (Espirito Santo vs Rio de Janeiro) and therefore was not labelled as a paralectotype.

Additional material examined. BRAZIL: 19 , Bahia, Fry Coll.

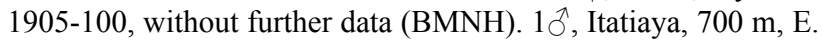
do Rio [east of Rio de Janeiro], 28.xi.1942, W. Zikán (MNRJ); 1 spec., labelled as "Paratype", sex undetermined, with the following labels: "Espirito / Santo" (written), followed by: "Schmidt" (written), followed by: "Fry Coll. / 1905-100" (printed), followed by: "Paratype" (yellow-margined round label, printed), followed by: "Phoxonotus fryi Lew." (written) (FMNH).

Diagnostic description. Because of the overall similarity of Phoxonotus fryi with P. venustus, the former species is provided only with diagnostic description outlining the differences between the two taxa. Body (Figs 61, 62) $\mathrm{PEL}=3.00-3.10 \mathrm{~mm} ; \mathrm{APW}=1.00 \mathrm{~mm} ; \mathrm{PPW}=2.20-2.50$ $\mathrm{mm} ; \mathrm{EW}=2.50-2.60 \mathrm{~mm} ; \mathrm{EL}=2.00-2.10 \mathrm{~mm}$. This species is externally very similar to $P$. venustus, differing from it chiefly in the shape of the spiculum gastrale, which is slightly dilated approximately half way along its length, forming a distinct "head" with characteristic, downwardly 

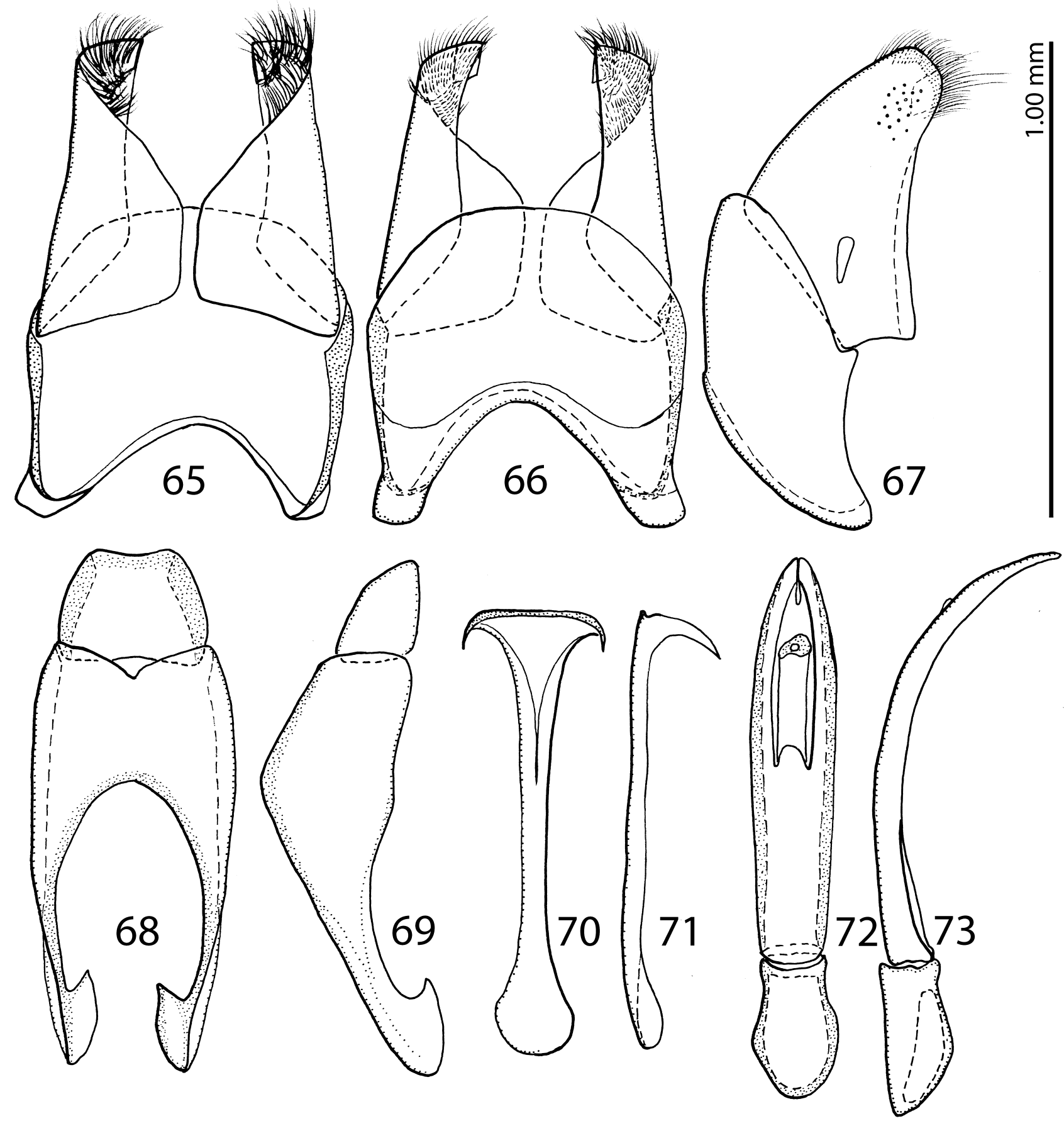

Fig. 65-73: Phoxonotus fryi, male. 65 - eighth sternite and tergite, ventral view; 66 - ditto, dorsal view; 67 - ditto, lateral view; 68 - ninth and tenth tergites, dorsal view; 69 - ditto, lateral view; 70 - spiculum gastrale, ventral view; 71 - ditto, lateral view; 72 - aedeagus, dorsal view; 73 - ditto, lateral view.

curved lateral "arms" (Fig. 70). In all other external morphological characters it resembles $P$. venustus Er.

Differential diagnosis. It differs from $P$. venustus mainly in the shape of its spiculum gastrale (compare Figs 57 and 70).

Biology. Reichensperger (1936) reports that the 9 specimens from Mendes (State of Rio de Janeiro, Brazil) are clearly attaphilous, as they were collected in nests of both A. cephalotes (L., 1758) and $A$. sexdens (L., 1758). The whereabouts of these 9 specimens are unknown.
Distribution. Brazil: Rio de Janeiro (Itatiaia city); Bahia state (without more precise data) (Fig. 74).

Remarks. Lewis (1902: 271) mentions a "straight crenulated line at the suture of the mesosternum" (= mesoventrite) as a "marked character of this species...". According to my observations, this "straight crenulated line at the suture of the mesosternum" (= meso-metaventral sutural stria) is present in all species of the genus, albeit variously "crenulated". Based on the external morphology and most of the characters of its genitalia it is possible that this species is synonymous with Erichson's P. venustus, which 


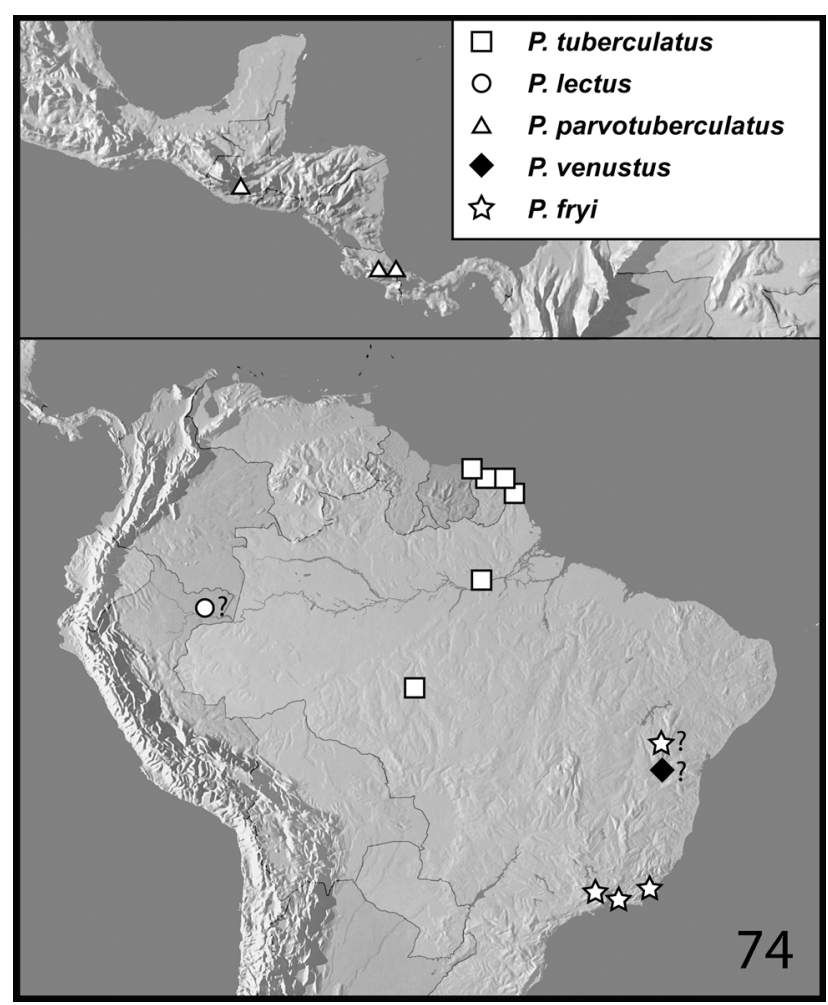

Fig. 74. Maps showing the distribution of the genus Phoxonotus.

Lewis combined with Phoxonotus in his 1886 paper, citing "ten [sic!; he probably meant "the" instead of "ten"] disposition of the tubercles on the thorax and the arrangement of the elytral striae" as the characters of $P$. venustus, which would surely differentiate it from both $P$. tuberculatus and P. fryi (Lewis 1886: 280). Lewis most likely never examined the type specimen of $P$. venustus Erichson and it is uncertain what he exactly meant by the disposition of the tubercles on the thorax and the arrangement of elytral striae.

\section{DISCUSSION}

Because of the structure of its prosternum and the position and shape of the antennal cavity, Photoxonotus used to be historically (see, e.g., Bickhardt, 1914, 1916 or Mazur, 1984) classified among the Dendrophilinae; and even after its placement in the Saprininae (Mazur, 1997, based on Wenzel's unpublished manuscripts) it was regarded as transitional between the groups (Ślipiński \& Mazur, 1999: 210). Having examined all the described and one undescribed species of this genus I conclude that the atypical form and placement of the antennal cavity (present in members of the nominotypical subgenus) is most likely derived from the "normal" condition (= plesiomorphic) in Saprininae, where the antennal cavity is formed by the prosternum and outer lateral costa of the antennal groove (sensu Lackner, 2010). It was most likely this character state, first observed and described by Marseul (1862), that cast doubt on the exact sub-familial placement of Phoxonotus. The members of the newly established subgenus Alienosternus, although as the name suggests have a "weird sternum", in fact have the typical arrangement and placement of the antennal cavity for the subfamily Saprininae. I believe that only one independent modification of the placement and form of the antennal cavity occurred in the genus: from the "normal" (= plesiomorphic) antennal cavity formed by the outer lateral costa of the antennal groove and prosternal process (found in Alienosternus) to the apomorphic state, in which the small antennal cavity is formed by the ventral part of the composite plate (sensu Ôhara, 1994), found in the subgenus Phoxonotus. The members of these two subgenera otherwise share several synapomorphies: (1) deeply incised base of the prosternum, formed to accommodate the acutely angulate apex of mesoventrite; (2) unique tubercles on pronotum and/or elytra; (3) accessory sclerite on eighth sternite of male genitalia; (4) widely interrupted frontal stria prolonged onto the clypeus; (5) apices of pronotum acute; (6) carinate and almost complete marginal and inner subhumeral striae; and (7) absence of sutural elytral stria. Most of these character states are possible autapomorphies of this genus. In the light of so many distinctive characters, and absence of "true" morphological modifications of the Dendrophilinae (e.g., presence of "deep lateral groove of the prosternum demonstrated to receive the strongly developed and hooked protibial spur in repose that forms an interlocking mechanism holding fore legs covering the antenna from below"; Ślipiński \& Mazur, 1999: 218) I do not consider Phoxonotus a "basal" member of the Saprininae or a "transitional form" between groups.

Although Ślipiński \& Mazur (1999: 228) state that the Reichardt's organ (sensory structures of the antennal club) is "indistinct or absent in Phoxonotus", I was able to locate two distinct vesicles inside the antennal club. According to Ślipiński \& Mazur (1999: 216), who based their results on an unknown species of Phoxonotus from Costa Rica, the antennal cavity in the subgenus Phoxonotus is "weakly developed, but positioned in an impression or cavity on inner portion of prosternum adjacent to the prosternal keel". As I was unable to check their specimen, I can only guess that theirs' was the derived state found in the subgenus Phoxonotus. On the other hand, the true "basal" character states of the subfamily, as indicated by my morphological studies (Lackner, 2014), such as presence of a lacinial hook (uncus) or longitudinally divided ninth tergite in the genitalia, are absent in Phoxonotus. Perhaps in the nominotypical subgenus the position and placement of the antennal club in repose in a small cavity on the ventral part of the composite plate does give members of the subgenus Phoxonotus more exposure or sensitivity; the reasons for which remain merely speculative. Discovery and comparison of larvae of both subgenera and/or molecular characters would perhaps present an independent character system(s) for checking their inter-relationships.

ACKNOWLEDGEMENTS. I thank my wife P. Artimová for help with the Latin subgeneric name and the new specific epithet for Phoxonotus; I am likewise indebted for her help with Adobe Illustrator CS3. Curators of the aforementioned museums are thanked for their help with the specimens. I am thankful to A. Pütz (Eisenhüttenstadt, Germany) and P. Schüle (Herrenberg, Germany) for their help with the German language. M. Caterino (Clemson, USA) is especially thanked for providing the map of South and Central America. This research received support from 
the SYNTHESYS Project (http://www.synthesys.info/), which is financed by the European Community Research Infrastructure Action under the FP7 Integrating Activities Program. Likewise this research was partially supported by a grant from the Faculty of Forestry and Wood Sciences, Specific research, grant n. B06/15. Special thanks are due to two anonymous reviewers and editor of the European Journal of Entomology who provided numerous corrections and suggestions, which increased the quality of this paper.

\section{REFERENCES}

Bickhardt H. 1914: Die System der Histeriden (Vorläufige Mitteilung). (22. Beitrag zur Kenntnis der Histeriden). —Entomol. Bl. 10: 305-308.

BicKHARDT H. 1916: Histeridae. In Wytsman P. (ed.): Genera Insectorum, Fasc. 166a. La Haye, 302 pp.

ERICHSON W.F. 1834: Uebersicht der Histeroides der Sammlung. In Klug J.C.F. (ed.): Jahrbücher der Insectenkunde mit besonderer Rücksicht auf die Sammlung in Köningl. Museum in Berlin. Erster Band. Enslin, Berlin, viii + 296 pp.

Dégallier N. \& KanaAr P. 2001: Coleoptera Histeridae de Guyane française. III. Compléments au catalogue et notes systématiques. - Bull. Soc. Entomol. Fr. 106: 199-214.

KANAAR P. 1997: New attaphilous Histeridae from Suriname. Zool. Med. Leiden 71: 277-286.

LACKNER T. 2009a: Revision of the genus Saprinillus, with description of a new species (Coleoptera: Histeridae). - Folia Heyrovskyana (A) 16: 107-118.

LACKNER T. 2009b: Revision of the genus Zorius (Coleoptera: Histeridae). - Folia Heyrovskyana (A) 16: 119-129.

LACKNER T. 2009c: Revision of the genus Terametopon, with description of new species (Coleoptera: Histeridae). - Folia Heyrovskyana (A) 17: 43-72.

LACKNER T. 2010: Review of the Palaearctic genera of Saprininae (Coleoptera: Histeridae). - Acta Entomol. Mus. Nat. Pragae (Suppl.) 50: 1-254.

LACKNER T. 2011a: On the identity of Chalcionellus orcinus Reichardt, 1932 and Chalcionellus libanicola (Marseul, 1870) (Coleoptera: Histeridae). - Acta Entomol. Mus. Nat. Pragae 51: 505-515.

LACKNER T. 2011b: Revision of the genus Alienocacculus Kanaar 2008 (Coleoptera: Histeridae: Saprininae). - Folia Heyrovskyana 19: 139-157.

LACKNER T. 2012: Revision of the genus Xenonychus Wollaston, 1864. - Acta Entomol. Mus. Nat. Pragae 52: 147-159.

LACKNER T. 2013a: Revision of the genus Ctenophilothis Kryzhanovskij, 1987 (Coleoptera: Histeridae: Saprininae). Zootaxa 3691: 273-282.

LACKNER T. 2013b: Elevation of Pilisaprinus to full generic status with notes on the evolution of termitoxeny in the Saprininae (Coleoptera: Histeridae). - Acta Entomol. Mus. Nat. Pragae 53: 623-632.

LACKNER T. 2013c: Afroprinus cavicola gen. et sp. n. from the Afrotropical region with notes on cave-dwelling Saprininae (Coleoptera, Histeridae). — ZooKeys 294: 57-73.
LACKNER T. 2014a: Revision of the genus Reichardtiolus Kryzhanovskij, 1959 (Coleoptera, Histeridae, Saprininae). — ZooKeys 379: 1-27.

LACKNER T. 2014b: Revision of the genus Hemisaprinus Kryzhanovskij, 1976 (Coleoptera, Histeridae, Saprininae). — ZooKeys 429: 101-130.

LACKNER T. 2014c: Description of the male of Ctenophilothis altus (Lewis, 1885): supplement to the revision of the genus Ctenophilothis Kryzhanovskij, 1987 (Coleoptera: Histeridae: Saprininae). - Dt. Entomol. Z. 61: 121-122.

LACKNER T. 2014d: Phylogeny of the Saprininae reveals interesting ecological shifts in the history of the subfamily (Coleoptera: Histeridae). - Zool. J. Linn. Soc. 172: 521-555.

LACKNER T. 2015: Revision of the genus Exaesiopus Reichardt, 1926. - ZooKeys 479: 65-108.

LACKNER T. \& Gomy Y. 2013: Malagasyprinus, a new genus of the Saprininae subfamily from Madagascar with description of two new species (Coleoptera: Histeridae: Saprininae) (First contribution to the knowledge of the Histeridae of Madagascar). ZooKeys 333: 55-76.

LACKNER T. \& Gomy Y. 2014: Sarandibrinus, a new genus of Saprininae subfamily from Madagascar (Coleoptera, Histeridae) (Second contribution to the knowledge of the Histeridae of Madagascar). — ZooKeys 427: 109-125.

LewIS G. 1879: Descriptions of some new Histeridae (Coleoptera) in genera hitherto represented by single species. - Entomol. Monthly Mag. 16: 60-61.

LEWIS G. 1886: On the nomenclature of sundry Histerids, including a note on a fourth species of European Dendrophilus. Wien. Entomol. Ztg 5: 280.

LEwIS G. 1902: On a new species of Histeridae and notices of others. - Ann. Mag. Nat. Hist. 7: 265-278.

LEwIS G. 1908: On a new species of Histeridae and notices of others. - Ann. Mag. Nat. Hist. 8: 137-160.

LewIS G. 1915: Note on the taxonomy of the Histeridae. - Entomol. Monthly Mag. 60: 289.

Marseul S.A. 1862: Supplement à la monographie des histérides (Suite). - Ann. Soc. Entomol. Fr. (Sér. 4) 2: 5-48, 437-516.

Mazur S. 1984: A world catalogue of Histeridae. - Pol. Pis. Entomol. 54: 1-376.

MAzUR S. 1997: A world catalogue of the Histeridae (Coleoptera: Histeridae). - Genus (Suppl.): 1-373.

Mazur S. 2011: A Concise Catalogue of the Histeridae (Coleoptera). Warsaw University of Life Sciences, SGGW Press, Warsaw, $332 \mathrm{pp}$.

ReICHENSPERGER A. 1935: Beitrag zur Kenntnis attaphiler Histeriden aus Brasilien (Col.). - Rev. Entomol. Rio de J. 5: $25-32$.

ŚLIPIŃSKI A. \& MAZUR S. 1999: Epuraeosoma, a new genus of Histerinae and phylogeny of the family Histeridae (Coleoptera, Histeroidea). — Ann. Zool. 49: 209-230.

Received September 22, 2015; revised and accepted November 12, 2015 Published online March 1, 2016 